\title{
A Modern View of Pharmacokinetics ${ }^{1}$
}

\author{
John G. Wagner ${ }^{2}$
}

\begin{abstract}
A modern view of pharmacokinetics must include both linear and nonlinear systems. Evidence of nonlinearities in pharmacokinetics go back to the early 1930's with the origination of the concept that ethyl alcohol is eliminated at a fixed rate independent of its concentration in the body. This paper contains references to over 160 articles which suggest evidence on nonlinearities in drug absorption, distribution, metabolism and excretion, and the pharmacokinetics of drug action. These works are reviewed in a format of six tables: Evidence for Nonlinearities in Drug Absorption; Drug Distribution; Drug Metabolism; Renal Excretion of Drugs and Metabolites; Biliary Excretion of Drugs; and Pharmacokinetics of Drug Action. Special attention is given to the equations used to describe nonlinear kinetics, the recognition of nonlinearities, nonlinear models, and the fitting of data. Seven guidelines are presented for use in possible future pharmacokinetic studies involving drug kinetics.
\end{abstract}

KEY WORDS: linear pharmacokinetics; nonlinear pharmacokinetics; plasma protein binding; tissue binding; Michaelis-Menten kinetics; nonlinear absorption; nonlinear distribution; nonlinear metabolism; nonlinear renal excretion; nonlinear biliary excretion.

\section{INTRODUCTION}

Publication of the mathematics of accumulation in the one-compartment open model by Widmark and Tandberg (1) and the two papers on the twocompartment open model by the organizer of this conference, Professor Torsten Teorell $(2,3)$, were the origins of pharmacokinetics. Many of us who have studied the literature of pharmacokinetics have been amazed at the insight and foresight embodied in Professor Teorell's two papers. The classical one- and two-compartment open linear models have withstood the test of time, have achieved accurate assessment of rates of absorption, metabolism, and excretion when applied to certain specific drugs, and have

Supported in part by Public Health Service Grant 5-P11-GM15559.

${ }^{1}$ Presented at the Conference on Pharamacology and Pharmacokinetics: Problems and Perspectives, October 30-November 1, 1972, at the Fogarty International Center, National Institutes of Health, Bethesda, Maryland. This paper, in a slightly different format, will be published in the Proceedings of the Conference by Plenum Press, New York.

${ }^{2}$ Upjohn Center for Clinical Pharmacology, University of Michigan, Ann Arbor, Michigan 48104. 
been very useful for predictive purposes. Undoubtedly in the future these classical models will continue to be as useful as they have in the the past. These classical pharmacokinetics models are based on systems of linear differential equations, which may conveniently be integrated by the use of Laplace transforms. Kinetic linearity was defined by Krüger-Thiemer (4) as direct proportionality of transfer rates to concentrations or concentration differences.

A modern view of pharmacokinetics must include both linear and nonlinear systems. For many years in the linear pharmacokinetic area authors spent a great deal of time and journal space deriving the equations they needed to interpret data. Recently, Benet and Turi (5) and Benet (6) made significant contributions in the linear pharmacokinetic area. The Benet method (6) allows one to write the Laplace transform for the amount of drug in any compartment of a mammillary model and to obtain the inverse Laplace transform (i.e., the final integrated equation) consisting of a sum of exponential terms. The method is highly recommended for those not familiar with the technique. Since Dr. Garrett has reviewed classical pharmacokinetics, I will spend most of my time comparing linear and nonlinear pharmacokinetics and discussing nonlinear pharmacokinetics.

\section{HISTORICAL}

Evidence of nonlinearities in pharmacokinetics goes back almost as far as the theory of linear pharmacokinetics. Widmark $(7,8)$ in the early 1930 s originated the concept that ethyl alcohol is eliminated at a fixed rate independent of its concentration in the body. After an oral dose of ethyl alcohol, a certain range of alcohol blood concentrations appear to give a straight line when the data are plotted on cartesian coordinate graph paper, but a line with concave decreasing curvature when plotted on semilogarithmic graph paper. Although Widmark's concept is still widely accepted and taught, it is really incorrect, as discussed in a paper by Wagner and Patel (9).

In performing the literature search for this review, I was rather amazed to find in my files over 160 articles which contained evidence of nonlinearities in drug absorption, distribution, metabolism, and excretion, and in the pharmacokinetics of drug action. This review is not intended to be an exhaustive search. In the area of pharmacokinetics of drug action, only reviews, and not original literature, are cited. Much of the literature has been summarized in a series of tables. Table I lists the evidence for nonlinearities in drug absorption, Table II the evidence for nonlinearities in drug distribution, Table III the evidence for nonlinearities in drug metabolism, Table IV the evidence for nonlinearities in renal excretion of drugs and metabolites, Table $\mathrm{V}$ the evidence for nonlinearities in biliary excretion of drugs, and 
Table I. Evidence for Nonlinearities in Drug Absorption

\begin{tabular}{|c|c|c|}
\hline Drug & Comments & Reference \\
\hline Several & $\begin{array}{l}\text { Mathematical description of carrier- } \\
\text { mediated transport across a membrane }\end{array}$ & $\begin{array}{l}\text { Wilbrandt and } \\
\text { Rosenberg (10) }\end{array}$ \\
\hline Several & $\begin{array}{l}\text { Mathematical aspects of effects of drugs on } \\
\text { active transport systems }\end{array}$ & Patlack (11) \\
\hline Riboflavin & $\begin{array}{l}\text { Saturable absorption process evident in } \\
\text { fasted subjects not evident when subjects } \\
\text { fed }\end{array}$ & Levy and Jusko (12) \\
\hline Antipyrine- $C^{14}$ & $\begin{array}{l}\text { Change in absorption rate with change in } \\
\text { intestinal blood flow rate }\end{array}$ & $\begin{array}{l}\text { Ochsenfahrt and } \\
\text { Winne (13) }\end{array}$ \\
\hline Griseofulvin & Nonlinear absorption curves in man & Rowland et al. (14) \\
\hline \multirow{2}{*}{$\begin{array}{l}\text { Folic acid and } \\
\text { 5-methyltetrahydro } \\
\text { folate }\end{array}$} & $\begin{array}{l}\text { Absorption obeyed Michaelis-Menten } \\
\text { kinetics }\end{array}$ & Hepner et al. (15) \\
\hline & $\begin{array}{l}\text { No evidence of saturable absorption } \\
\text { process }\end{array}$ & Strum et al. (16) \\
\hline Convallotoxin & $\begin{array}{l}\text { In vitro studies indicated active transport } \\
\text { mechanism for absorption }\end{array}$ & Lauterback (17) \\
\hline Barbiturates & $\begin{array}{l}\text { Absorption rates correlated with binding } \\
\text { to mucosal tissue }\end{array}$ & Kakemi et al. (18) \\
\hline $\begin{array}{l}\text { Acidic and basic } \\
\text { drugs }\end{array}$ & $\begin{array}{l}\text { Theoretical models for drug absorption } \\
\text { involving stagnant water layer }\end{array}$ & Suzuki et al. (19) \\
\hline Sulfaethidole & $\begin{array}{l}\text { Change in slope of first-order plot for } \\
\text { disappearance from intestinal lumen of } \\
\text { dog with change in intestinal blood flow } \\
\text { rate }\end{array}$ & Crouthamel et al. (20) \\
\hline Several & $\begin{array}{l}\text { Kinetics of absorption related to intestinal } \\
\text { blood flow rate }\end{array}$ & Winne (21) \\
\hline Several & Kinetics of carrier-mediated ion transport & Lauger and Stark (22) \\
\hline Guanethidine & $\begin{array}{l}\text { Percent of dose absorbed decreased with } \\
\text { increasing dose in man }\end{array}$ & $\begin{array}{l}\text { McMartin and } \\
\text { Simpson (23) }\end{array}$ \\
\hline $\begin{array}{l}p \text {-Substituted } \\
\text { acetanilide }\end{array}$ & $\begin{array}{l}\text { Hypothesized that tissue binding caused } \\
\text { nonlinearity of first-order plots in buccal } \\
\text { absorption test }\end{array}$ & $\begin{array}{l}\text { Dearden and } \\
\text { Tomlinson (24) }\end{array}$ \\
\hline Indomethacin & $\begin{array}{l}\text { Drug strongly bound to intestinal tissue } \\
\text { during absorption and binding was } \\
\text { dependent on } p \mathrm{H}\end{array}$ & Fuwa et al. (25) \\
\hline Pentobarbital & Delay in gastric emptying & Smith et al. (26) \\
\hline $\begin{array}{l}\text { Acidic and basic } \\
\text { drugs }\end{array}$ & $\begin{array}{l}\text { Theoretical models for drug absorption } \\
\text { which ignore stagnant water layer }\end{array}$ & $\begin{array}{l}\text { Wagner and Sedman } \\
\text { (27) }\end{array}$ \\
\hline Salicylamide & $\begin{array}{l}\text { Rate of appearance of glucuronide in } \\
\text { plasma, subsequent to intestinal wall } \\
\text { metabolism, rate-limited by transport } \\
\text { across the basal barrier rather than by } \\
\text { metabolism }\end{array}$ & $\begin{array}{l}\text { Barrr and Riegelman } \\
(28,29)\end{array}$ \\
\hline
\end{tabular}


Table II. Evidence for Nonlinearities in Drug Distribution

\begin{tabular}{|c|c|c|}
\hline Drug & Comments & Reference \\
\hline Several & $\begin{array}{l}\text { Mathematical description of drug } \\
\text { distribution }\end{array}$ & Jacquez et al. (30) \\
\hline $\begin{array}{l}\text { Fat emulsions and } \\
\text { chylomicrons }\end{array}$ & Kinetics of elimination from bloodstream & Hallberg et al. $(31-33)$ \\
\hline \multirow[t]{2}{*}{ Sulfobromophthalein } & Distribution and rate of uptake by liver & $\begin{array}{l}\text { Andersson et al. (34). } \\
\text { Goresky (35) }\end{array}$ \\
\hline & Day-to-day variation in elimination curves & $\begin{array}{l}\text { Winkler and Tygstrup } \\
(36)\end{array}$ \\
\hline Ouabain- $\mathrm{H}^{3}$ & $\begin{array}{l}\text { Distribution in plasma and uptake by } \\
\text { heart }\end{array}$ & Marks et al. (37) \\
\hline Guanethidine & Time course in plasma and tissues of rat & $\begin{array}{l}\text { Schanker and } \\
\text { Morrison }(38)\end{array}$ \\
\hline \multirow[t]{3}{*}{ Methotrexate } & $\begin{array}{l}\text { Distribution in mice, rats, dogs, and } \\
\text { monkeys }\end{array}$ & Henderson et al.(39) \\
\hline & Time- and dose-dependent tissue levels & Zaharko et al. (40) \\
\hline & $\begin{array}{l}\text { Flow-rate-limited model for distribution in } \\
\text { mice }\end{array}$ & Bischoff et al. (41) \\
\hline Kanamycin & $\begin{array}{l}\text { Nonlinear kinetics in perilymph from } \\
\text { scala vestibuli of guinea pigs }\end{array}$ & Stupp et al. (42) \\
\hline Aspirin & $\begin{array}{l}\text { Time courses in plasma and synovial fluid } \\
\text { different }\end{array}$ & Sholkoff et al. (43) \\
\hline \multirow[t]{4}{*}{ Bishydroxycoumarin } & Unusual interaction with plasma proteins & Nagashima et al. (44) \\
\hline & $\begin{array}{l}\text { Liver-plasma distribution affecting rate of } \\
\text { metabolism }\end{array}$ & Nagashima et al. (45) \\
\hline & Three-compartment open model & Nagashima et al. (46) \\
\hline & $\begin{array}{l}\text { Effect of plasma protein binding on } \\
\text { distribution and elimination in rats }\end{array}$ & $\begin{array}{l}\text { Levy and Nagashima } \\
\text { (47) }\end{array}$ \\
\hline Selenite-Se $\mathrm{e}^{75}$ & $\begin{array}{l}\text { Dose dependence of rapid disappearance } \\
\text { from blood }\end{array}$ & Oldendorf (48) \\
\hline Thiopental & $\begin{array}{l}\text { Flow-rate-limited model for thiopental } \\
\text { pharmacokinetics }\end{array}$ & $\begin{array}{l}\text { Bischoff and Dedrick } \\
\text { (49) }\end{array}$ \\
\hline Benzylpenicillin & Active transport from CSF to blood & Dixon et al. $(50)$ \\
\hline Digoxin & $\begin{array}{l}\text { Atrial tissue concentrations and plasma } \\
\text { concentrations }\end{array}$ & Binnion et al (51) \\
\hline Indocyanine green & Rapid and saturable uptake by liver & Paumgartner et al. (52) \\
\hline Diphenhydramine & Very rapid tissue binding in rhesus monkey & Darchet al. (53) \\
\hline Benzopyrene & $\begin{array}{l}\text { Exponential relationship between tissue } \\
\text { concentrations and oral dose }\end{array}$ & Rees et al. (54) \\
\hline Methacycline & Lung tissue and serum concentrations & Timmes et al. (55) \\
\hline \multirow[t]{2}{*}{ Methylene blue } & $\begin{array}{l}\text { Tissue levels in rat as function of dose } \\
\text { showed saturation effects }\end{array}$ & $\begin{array}{l}\text { DiSanto and Wagner } \\
(56,57)\end{array}$ \\
\hline & $\begin{array}{l}\text { Blood levels in dog as function of dose } \\
\text { showed nonlinearities }\end{array}$ & $\begin{array}{l}\text { DiSanto and Wagner } \\
\text { (57) }\end{array}$ \\
\hline $\begin{array}{l}\text { Erythromycin acid } \\
\text { erythromycin- } 2^{\prime} \text { - } \\
\text { propionate ester }\end{array}$ & $\begin{array}{l}\text { Most drug bound to tissues and only about } \\
1 \% \text { bound to plasma proteins }\end{array}$ & $\begin{array}{l}\text { Wiegand and Chun } \\
(58)\end{array}$ \\
\hline Duanomycin & $\begin{array}{l}\text { Rapidly taken up and tenaciously held by } \\
\text { tissues }\end{array}$ & Alberts et al. (59) \\
\hline Several & $\begin{array}{l}\text { Effect of perfusion rate and distribution } \\
\text { factors on elimination kinetics in a } \\
\text { perfused organ system }\end{array}$ & $\begin{array}{l}\text { Nagashima and Levy } \\
\text { (60) }\end{array}$ \\
\hline
\end{tabular}


Table II. Continued

\begin{tabular}{|c|c|c|}
\hline Drug & Comments & Reference \\
\hline Salicylate & $\begin{array}{l}\text { Decreasing blood } p \mathrm{H} \text { in rats associated } \\
\text { with increasing tissue concentrations }\end{array}$ & Hill (61) \\
\hline Secobarbital & $\begin{array}{l}\text { Tissue and blood levels did not obey zero- } \\
\text { or first-order kinetics }\end{array}$ & Somani et al. (62) \\
\hline Griseofulvin & $\begin{array}{l}\text { Dose-dependent kinetics in some dogs } \\
\text { attributed to changes in tissue } \\
\text { distribution }\end{array}$ & $\begin{array}{l}\text { Chiou and Riegelman } \\
\text { (63) }\end{array}$ \\
\hline Bupivacaine & $\begin{array}{l}\text { Semilogarithmic plasma concentration } \\
\text { plots showed continual curvature }\end{array}$ & Mather et al. (64) \\
\hline $\begin{array}{l}\text { Methylhydroxy- } \\
\text { coumarin }\end{array}$ & Tissue and plasma levels in the rat & $\begin{array}{l}\text { Tomura and Akera } \\
(65)\end{array}$ \\
\hline
\end{tabular}

Table III. Evidence for Nonlinearities in Drug Metabolism

\begin{tabular}{|c|c|c|}
\hline Drug & Comments & Reference \\
\hline \multirow[t]{4}{*}{ Ethyl alcohol } & $\begin{array}{l}\text { Originated idea of fixed rate of } \\
\text { elimination-independent concentration } \\
\text { in body }\end{array}$ & Widmark $(7,8)$ \\
\hline & $\begin{array}{l}\text { Showed that apparently linear decline of } \\
\text { plasma alcohol concentration }\left(k_{0}\right) \\
\text { increased with increase in both dose of } \\
\text { alcohol and initial concentration }\left(C_{0}\right)\end{array}$ & Eggleton (66) \\
\hline & $\begin{array}{l}\text { Showed that serum alcohol concentration, } \\
\text { time data fit the integrated form of the } \\
\text { Michaelis-Menten equation }\end{array}$ & $\begin{array}{l}\text { Lundquist and } \\
\text { Wolthers (67) }\end{array}$ \\
\hline & $\begin{array}{l}\text { Showed mathematically that } 1 / k_{0} \text { should } \\
\text { be iinearly related to } 1 / C_{0}, \text { but } V_{m} \text { and } \\
K_{m} \text { change in same subject from day to } \\
\text { day }\end{array}$ & Wagner and Patel (9) \\
\hline Benzoic acid & $\begin{array}{l}\text { Conjugation with glycine limited by } \\
\text { availability of glycine }\end{array}$ & Bray et al. (68) \\
\hline \multirow[t]{5}{*}{ Salicylic acid } & $\begin{array}{l}\text { Evidence of saturation effects in formation } \\
\text { and active tubular secretion of salicylurate } \\
\text { and salicylphenolic glucuronide following } \\
4-\mathrm{g} \text { oral dose of sodium salicylate in } \\
\text { man; evidence of active tubular } \\
\text { secretion of salicylate and salicyl acyl } \\
\text { glucuronide }\end{array}$ & $\begin{array}{l}\text { Schachter and Manis } \\
\text { (69) }\end{array}$ \\
\hline & $\begin{array}{l}\text { Intensive investigation of capacity-limited } \\
\text { formation of salicylurate }\end{array}$ & Levy et al. $(70-77)$ \\
\hline & $\begin{array}{l}\text { Capacity-limited formation of salicyl } \\
\text { phenolic glucuronide }\end{array}$ & Levy et al. $(78-80)$ \\
\hline & $\begin{array}{l}\text { Competitive inhibition of salicylic acid } \\
\text { conjugation with glycine and mutual } \\
\text { inhibition in glucuronide formation }\end{array}$ & Levy et al. $(77,81-83)$ \\
\hline & $\begin{array}{l}\text { Completed model to explain salicylate } \\
\text { pharmacokinetics }\end{array}$ & Levy et al. (80) \\
\hline $\begin{array}{l}\text { Salicylsalicylic acid, } \\
\text { aspirin, salicylic } \\
\text { acid }\end{array}$ & Metabolic kinetics & Nordquist et al. (84) \\
\hline
\end{tabular}


Table III. Continued

\begin{tabular}{|c|c|c|}
\hline Drug & Comments & Reference \\
\hline \multirow[t]{3}{*}{ Salicylamide } & $\begin{array}{l}\text { Conjugation with sulfate limited by } \\
\text { availability of sulfate }\end{array}$ & $\begin{array}{l}\text { Levy and Matsuzawa } \\
\text { (85) }\end{array}$ \\
\hline & Pharmacokinetics of elimination in man & $\begin{array}{l}\text { Levy and Matsuzawa } \\
(86)\end{array}$ \\
\hline & $\begin{array}{l}\text { Effect of capacity-limited metabolism on } \\
\text { plasma levels of unchanged drug }\end{array}$ & $\begin{array}{l}\text { Barr and Riegelman } \\
\text { (87) }\end{array}$ \\
\hline $\begin{array}{l}\text { Salicyclic acid and } \\
\text { salicylamide }\end{array}$ & Mutual inhibition in glucuronide formation & $\begin{array}{l}\text { Levy and Procknal } \\
\text { (82) }\end{array}$ \\
\hline $\begin{array}{l}\text { Benzoic acid and } \\
\text { salicylic acid }\end{array}$ & Simultaneous conjugation with glycine & Amsel and Levy (83) \\
\hline $\begin{array}{l}\text { Acetaminophen and } \\
\text { salicylamide or } \\
\text { salicylic acid }\end{array}$ & Biotransformation interaction & $\begin{array}{l}\text { Levy and Yamada (88), } \\
\text { Levy and Regardh } \\
\text { (89) }\end{array}$ \\
\hline Isoniazid & $\begin{array}{l}\text { Inhibition of acetylation by p-amino- } \\
\text { benzaldehyde }\end{array}$ & Kakemi et al. $(90)$ \\
\hline p-Aminobenzoic acid & $\begin{array}{l}\text { Percent acetylation related to dose, rate of } \\
\text { administration, and nutritional factors }\end{array}$ & Drucker et al. (91) \\
\hline $\begin{array}{l}\text { Diphenylhydrantoin, } \\
\text { phenylbutazone, } \\
\text { biscoumacetate, } \\
\text { probenecid }\end{array}$ & $\begin{array}{l}\text { Changes in elimination half-life and } \\
\text { apparent volume of distribution with } \\
\text { dose }\end{array}$ & Dayton et al. (92) \\
\hline Bishydroxycoumarin & Elimination kinetics in several species & Nagashima et al. (93) \\
\hline Warfarin & Elimination kinetics in several species & $\begin{array}{l}\text { Nagashima and Levy } \\
\text { (94) }\end{array}$ \\
\hline Novobiocin & $\begin{array}{l}\text { Elimination half-life dependent on dose in } \\
\text { adults and children }\end{array}$ & $\begin{array}{l}\text { Wagner and } \\
\text { Damiano }(95)\end{array}$ \\
\hline $\begin{array}{l}\text { 2-Pyridinealdoxime } \\
\text { methochloride }\end{array}$ & $\begin{array}{l}\text { Log-log relationship between peak plasma } \\
\text { concentration and dose }\end{array}$ & $\begin{array}{l}\text { Kondritzer et al. (96) } \\
\text { Sidell et al. }(97)\end{array}$ \\
\hline Heparin & $\begin{array}{l}\text { Change in elimination half-life and } \\
\text { apparent volume of distribution with dose }\end{array}$ & Estes et al. (98) \\
\hline \multirow[t]{2}{*}{ Tetracycline } & $\begin{array}{l}\text { Area under serum concentration curve at } \\
\text { equilibrium state averaged twice the } \\
\text { area from } 0 \text { to } \infty \text { after single dose }\end{array}$ & Wagner (99) \\
\hline & $\begin{array}{l}\text { Apparent increase in elimination half-life } \\
\text { after multiple dosing }\end{array}$ & $\begin{array}{l}\text { Doluisio and Dittert } \\
(100)\end{array}$ \\
\hline Acetanilide & $\begin{array}{l}\text { Formation of 4-hydroxyacetanilide shown } \\
\text { to obey Michaelis-Menten kinetics }\end{array}$ & Shibasaki et al. (101) \\
\hline \multirow[t]{5}{*}{ Diphenylhydantoin } & $\begin{array}{l}\text { Plasma levels following IV administration } \\
\text { in man }\end{array}$ & Glazko et al. (102) \\
\hline & $\begin{array}{l}\text { IV administration in man indicated dose- } \\
\text { dependent kinetics did not occur }\end{array}$ & $\begin{array}{l}\text { Suzuki et al. (103), } \\
\quad \text { Blum et al. (104) }\end{array}$ \\
\hline & $\begin{array}{l}\text { Oral administration in man indicated dose- } \\
\text { dependent kinetics did occur }\end{array}$ & $\begin{array}{l}\text { Arnold and Gerber } \\
\quad(105)\end{array}$ \\
\hline & $\begin{array}{l}\text { Studies in mice and rats indicated dose- } \\
\text { dependent kinetics did occur }\end{array}$ & Gerber et al. $(106,107)$ \\
\hline & $\begin{array}{l}\text { Human and rat data fit with integrated } \\
\text { form of Michaelis-Menten equation }\end{array}$ & $\begin{array}{l}\text { Gerber and Wagner } \\
(108)\end{array}$ \\
\hline Several & $\begin{array}{l}\text { Properties of the Michaelis-Menten } \\
\text { equation and its integrated form which are } \\
\text { useful in pharmacokinetics }\end{array}$ & Wagner (109) \\
\hline Amylobarbitone & $\begin{array}{l}\text { Influence of dose on distribution and } \\
\text { elimination kinetics }\end{array}$ & $\begin{array}{l}\text { Balasubramaniam } \\
\text { et al. }(110)\end{array}$ \\
\hline
\end{tabular}


Table IV. Evidence for Nonlinearities in Renal Excretion of Drugs and Metabolites

\begin{tabular}{|c|c|c|}
\hline Drug & Comments & Reference \\
\hline Several & $\begin{array}{l}\text { Renal excretion of weak organic acids and } \\
\text { bases }\end{array}$ & Weiner et al. (111-113) \\
\hline Bile acids & Saturable reabsorptive process & Weiner et al. (114) \\
\hline Amphetamine & $\begin{array}{l}\text { Rhythmic urinary excretion due to variable } \\
\text { urine } p H\end{array}$ & $\begin{array}{l}\text { Beckett and Rowland } \\
\text { (115) }\end{array}$ \\
\hline $\begin{array}{l}\text { PAH and other } \\
\text { organic acids }\end{array}$ & $\begin{array}{l}\text { Kinetic studies on transport in isolated } \\
\text { renal tubules }\end{array}$ & Huang and Lin (116) \\
\hline Riboflavin & Saturable reabsorptive process & Jusko et al. $(117,118)$ \\
\hline Sulfonamides & Diurnal variations in elimination rate & Dettli and Spring (119) \\
\hline $\begin{array}{l}\text { Basic and acidic } \\
\text { drugs }\end{array}$ & $\begin{array}{l}\text { Use of analog computer to predict } \\
\text { reabsorption and excretion }\end{array}$ & Beckett et al. $(120,121)$ \\
\hline $\begin{array}{l}\text { Anisotropine } \\
\text { methylbromide } \\
\text { and } \\
\text { propantheline }\end{array}$ & Periodic excretion peaks & Pfeffer et al. $(122)$ \\
\hline Several & $\begin{array}{l}\text { Simultaneous chemical reaction and } \\
\text { diffusion model for uphill renal transport }\end{array}$ & Shibasaki et al.(123) \\
\hline Acetaminophen & $\begin{array}{l}\text { Formation of metabolite more rapid than } \\
\text { excretion of metabolite }\end{array}$ & Shibasaki et al. (124) \\
\hline Methylene blue & Periodic excretion peaks in man & $\begin{array}{l}\text { DiSanto and Wagner } \\
\text { (125) }\end{array}$ \\
\hline $\begin{array}{l}p \text {-Methyl mandelic } \\
\text { acid }\end{array}$ & $\begin{array}{l}\text { Michaelis-Menten kinetics of renal tubular } \\
\text { secretion }\end{array}$ & $\begin{array}{l}\text { Nagwekar and } \\
\text { Unnikrishnan (126) }\end{array}$ \\
\hline
\end{tabular}

Table V. Evidence for Nonlinearities in Biliary Excretion of Drugs

\begin{tabular}{|c|c|c|}
\hline Drug & Comments & Reference \\
\hline Several & Concentrative transfer from blood to bile & Schanker (127) \\
\hline Sulfobromophthalein & Transport maximum & Schoenfieid et al. (128) \\
\hline Several & $\begin{array}{l}\text { Influence of enterohepatic circulation on } \\
\text { toxicity of drugs }\end{array}$ & Williams et al. (129) \\
\hline Tetracycline & Active transport into bile & Lanman et al. (130) \\
\hline Indomethacin & Role of enterohepatic circulation & Yesair et al. (131) \\
\hline Methyl orange & $\begin{array}{l}\text { Successive demethylation and biliary } \\
\text { secretion }\end{array}$ & O'Reilly et al. (132) \\
\hline Riboflavin & $\begin{array}{l}\text { Two nonlinear processes work in opposite } \\
\text { directions; biliary excretion in rat } \\
\text { increases disproportionately with increasing } \\
\text { body levels; tissue binding also nonlinear }\end{array}$ & $\begin{array}{l}\text { Axelson and Gibaldi } \\
\text { (133) }\end{array}$ \\
\hline
\end{tabular}


Table VI. Evidence for Nonlinearities in Pharmacokinetics of Drug Action

\begin{tabular}{ll}
\hline \multicolumn{1}{c}{ Subject matter } & \multicolumn{1}{c}{ Reference } \\
\hline $\begin{array}{l}\text { Nonlinear equation for relating response to drug concentration } \\
\text { Nonlinear equation relating turnover time of goldfish to } \\
\text { ethanol concentration in bathing fluid }\end{array}$ & $\begin{array}{l}\text { Wagner (134) } \\
\text { DiSanto and Wagner (135) }\end{array}$ \\
$\begin{array}{l}\text { Dose-dependent decline of pharmacological effects of drugs } \\
\text { with linear pharmacokinetic characteristics }\end{array}$ & Gibaldi and Levy (136) \\
$\begin{array}{l}\text { Relationships between drug concentration and response } \\
\begin{array}{l}\text { Pharmacokinetics of drug action } \\
\text { Relationship between dose and plateau levels of drugs } \\
\text { eliminated by parallel first-order and capacity-limited kinetics }\end{array}\end{array}$ & $\begin{array}{l}\text { Wagner (137) } \\
\text { Levy and Gibaldi (138) } \\
\end{array}$ \\
\hline
\end{tabular}

Table VI the evidence for nonlinearites in pharmacokinetics of drug action. It may be well that I have missed some significant references, and to the authors of those papers I apologize. However, Tables I-VI summarize the references I could readily find.

\section{COMPARISON OF LINEAR AND NONLINEAR PHARMACOKINETICS}

\section{Drug Absorption}

In linear pharmacokinetics, the process of drug absorption has usually been described mathematically by one or two first-order processes. KrügerThiemer $(4,140,141)$ stated that deviations from linear drug absorption kinetics may result from low solubility of the drug, from a low rate of dissolution, from many different types of sustained release preparations, and from saturable active absorption processes. In addition, one may add the following: fluctuations and changes in intestinal blood flow rate, as result of the work of Ochsenfahrt and Winne (13), Crouthamel et al. (20), and Winne (21); the change in $\mathrm{pH}$ of luminal contents as a basic, acidic, or amphoteric drug moves down the gastrointestinal tract, as the result of the work of Shore et al. (142) and Hogben et al. (143) and the theoretical papers of Suzuki et al. (19,144) and Wagner and Sedman (27); and the possible effects of binding of drugs to mucosal tissue, as a result of the work of Kakemi et al. (18), Dearden and Tomlinson (24), and Fuwa et al. (25). Delay in gastric emptying, such as caused by food in the stomach, enteric-coated tablets, sustained-release preparations, anticholinergic agents, etc., will also cause nonlinearities in the absorption process. The work of Rowland et al. (14) with griseofulvin in man illustrates. that administration of even a micronized drug powder yields absorption data which cannot be fitted well by simple first-order kinetics. 


\section{Metabolism and Active Tubular Secretion in the Kidney}

Figure 1 compares linear and nonlinear pharmacokinetics with respect to metabolism and active tubular secretion in the kidney. At the top, a plot of $-d C / d t$ vs. $C$ is linear, in conformity with the first-order rate equation $-d C / d t=K C$. At the bottom, a plot of $-d C / d t$ vs. $C$ gives a curved line, which approaches an asymptote $\left(-d C / d t \rightarrow V_{m}\right.$ as $\left.C \rightarrow \infty\right)$, in conformity with the equation of Michaelis and Menten (145), shown inset in the figure. It should be noted that the $K=2.2$ line at the top is really the tangent line to the $-d C / d t$ vs. $C$ plot at the bottom, since $V_{m} / K_{m} \rightarrow$ a contant (2.2) as $C \rightarrow 0$.
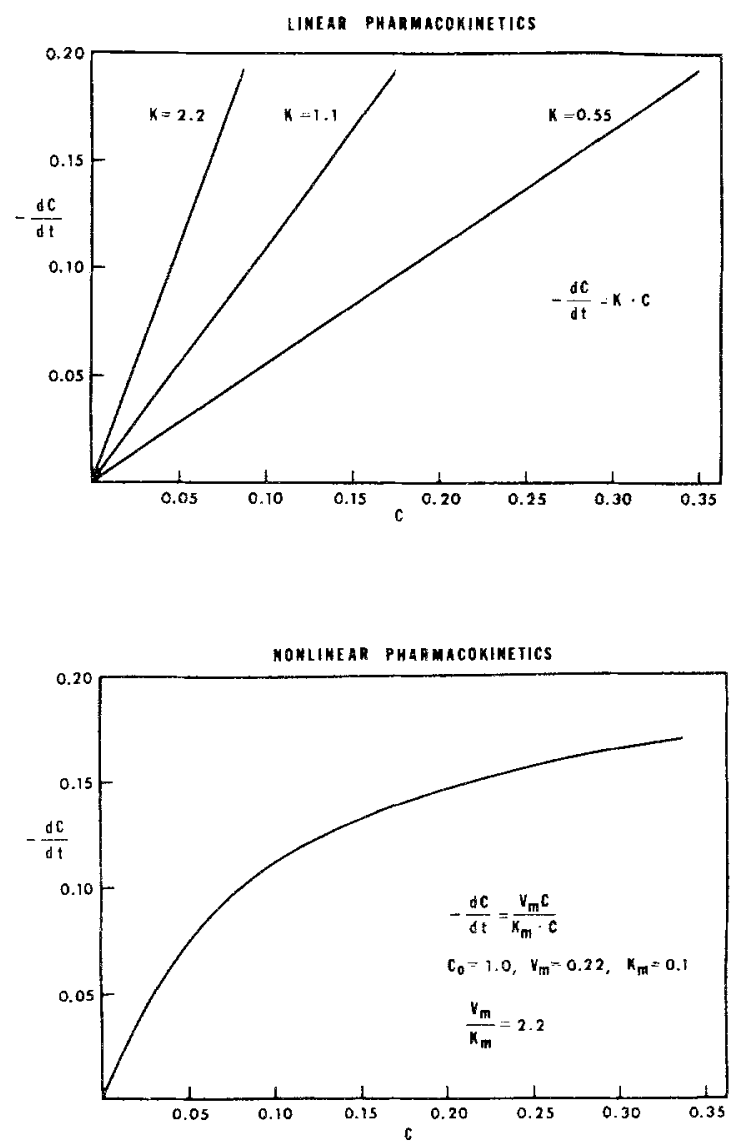

Fig. 1. Comparison of linear and nonlinear pharmacokinetics with respect to metabolism and active tubular secretion. See text for explanation. 
If Michaelis-Menten kinetics are obeyed, the percent saturation of the enzyme is given by

$$
-\frac{d C / d t}{V_{m}} \times 100=\frac{C}{K_{m}+C} \times 100
$$

It is the relative values of $K_{m}$ and $C$ which determine whether the MichaelisMenten equation should be "collapsed" to a zero-order or first-order rate expression. The fundamental assumptions behind linear pharmacokinetics are that (a) saturable rate processes may be "collapsed" to first-order rate equations, and (b) saturable binding processes may be "collapsed" to the equation of a straight line. In actual practice, these both involve the approximation of a segment of a gently curving line by a straight line. The data in Table VII, calculated using equation 1 and literature values of $K_{m}$, suggest that the Michaelis-Menten equation should not be "collapsed" to a zeroorder rate expression at least for salicylate, blood alcohol, and diphenylhydantoin. The computer simulation of salicylate urinary excretion data by Levy et al. (80), the computer fitting of whole capillary blood alcohol concentrations by Wagner and Patel (9), and the plasma diphenylhydantoin concentration data by Gerber and Wagner (108) support this statement. The estimation of the $V_{m}$ and $K_{m}$ of the Michaelis-Menten equation from blood concentration or urinary excretion data is about as easy with a modern computer as the estimation of a first-order rate constant. Since the $K_{m}$ and $V_{m}$ values obtained will usually provide an adequate description of the kinetics at all dose levels, pharmacokineticists in the future may wish to use this approach rather than report a series of rate constants or half-lives of elimination which vary with the dose administered.

\section{Uptake of Drug by Tissues}

Figure 2 compares linear and nonlinear pharmacokinetics with respect to the uptake of drugs by tissues. At the top is the theoretical prediction of the amount of drug in the tissues as a function of dose for the two-compartment open model with rapid intravenous injection. The appropriate equation from which the lines were drawn is shown inset in the figure. The model predicts that the amount of drug in tissues, $A_{2}$, will be a linear function of dose administered, for a fixed value of time, $t$. The types of curves one expects in nonlinear pharmacokinetics is indicated at the bottom of the figure. The asymptotic nature of the curves results from the assumption that there is a limiting amount of drug that can be taken up by the tissues. This appears reasonable since there is obviously only a certain amount of each kind of tissue in the body. The curves shown in Fig. 2 were generated as follows: Values of $A=10, B=1$, and $K=2.75$ were assigned, and equation 2 of 
Table VII. Calculation of Percent Saturation of "Enzyme System" from Available Literature Values of $K_{m}$ of the Michaelis-Menten Equation $^{a}$

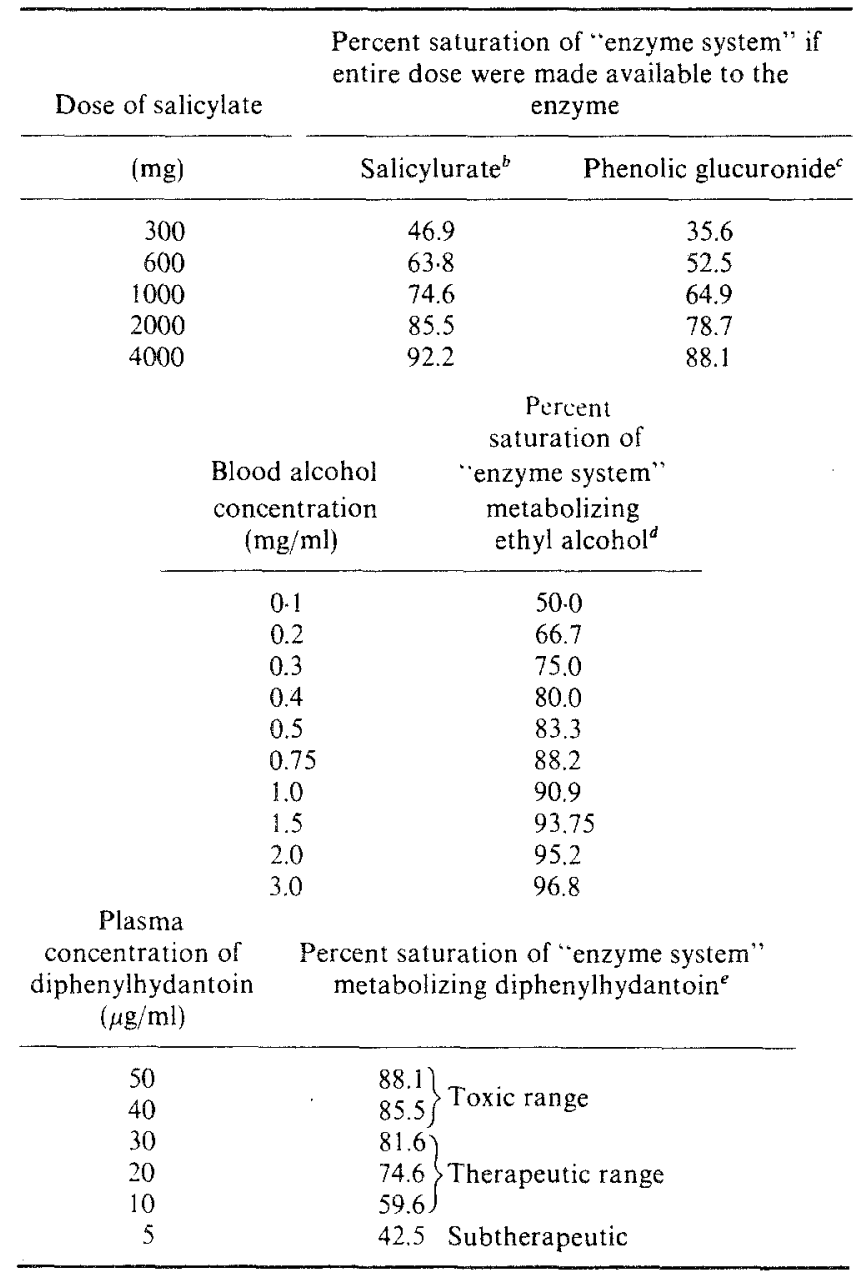

${ }^{a}$ Calculated from equation 1 in text.

${ }^{b}$ Based on the $K_{m}$ value of $340 \mathrm{mg}$ of Levy et al. (80) for subject A. 'Based on the $K_{m}$ value of $542 \mathrm{mg}$ of Levy et al. (80) for subject A. ${ }^{d}$ Based on the $K_{m}$ value of $0.1 \mathrm{mg} / \mathrm{ml}$ of Goldstein (146).

${ }^{e}$ Based on the $K_{m}$ value of $6.77 \mu \mathrm{g} / \mathrm{ml}$ of Gerber and Wagner (108). 

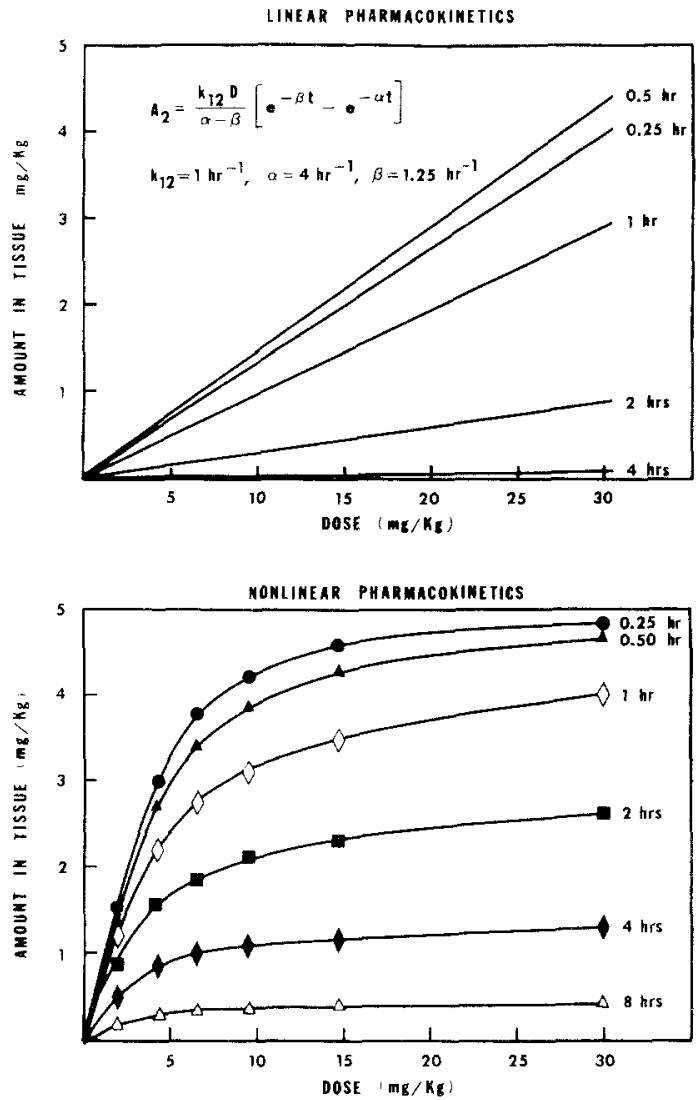

Fig. 2. Comparison of linear and nonlinear pharmacokinetics with respect to uptake of drug by tissues. See text for explanation.

Wagner (147) and DiSanto and Wagner (148) was numerically integrated for $C_{0}$ values of $0.5,2,5,10,20$, and 50 , corresponding to doses of $1.917,4.33$, $6.67,9.55,14.76$, and $29.9 \mathrm{mg} / \mathrm{kg}$, based on an assumed volume of distribution, $V$, of $0.5 \mathrm{liter} / \mathrm{kg}$. Hence the $C, t$ data generated fit the integrated form of equation 2 , shown as equation 3 . The amount

$$
d C / d t=-K C /\left[1+A B /(B+C)^{2}\right]
$$

of drug in the tissue, $T$, was

$$
t=\frac{1}{k}\left[\left(1+\frac{A}{B}\right) \ln \left(\frac{C_{0}}{C}\right)+\frac{A}{B} \ln \left\{\frac{B+C}{B+C_{0}}\right\}+A\left\{\frac{C-C_{0}}{(B+C)\left(B+C_{0}\right)}\right\}\right]
$$


calculated from a given value of $C$ by means of

$$
T^{\prime}=A^{\prime} C /(B+C)
$$

In equation 4, the value of $A^{\prime}$ employed was $A^{\prime}=A V=10 \times 0.5=5 \mathrm{mg} / \mathrm{kg}$. In the simulation, $A^{\prime}$ represented the maximum amount of drug, with dimensions of $\mathrm{mg} / \mathrm{kg}$ body weight, which could be taken up by tissues.

There is very little literature concerning the measurement of drug in various tissues of the body as a function of both time and dose. Recently, my coworkers have been generating such data. Figure 3 shows the data of DiSanto and Wagner (57) on the uptake of methylene blue in four tissues of the rat, presented differently than in the original paper. These are preliminary data since only one rat was studied at each dose. However, nonlinearity is very evident. Dr. Robert N. Smith, while at The Upjohn Center for Clinical Pharmacology, University of Michigan Medical School, administered diphenhydramine in doses of $4,6,8,12$, and $16 \mathrm{mg} / \mathrm{kg}$ by rapid intravenous injection and killed the rats at $1,5,15,30,60,120,180$, and 240 min after injection. Diphenhydramine was measured by a fluorometric method in brain, lung, heart, spleen, liver, and plasma of four rats at each time and each dose level. The tissue concentration and plasma concentration vs. time plots showed marked nonlinearties. The data will be published in the British

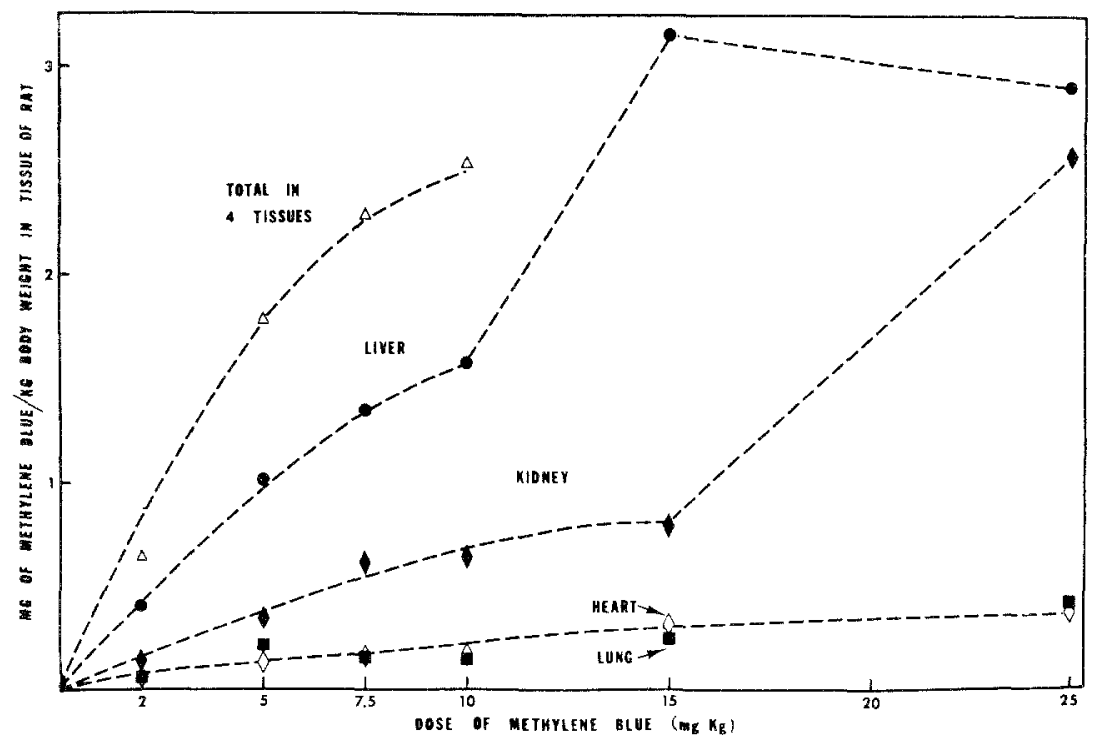

Fig. 3. Plot of $\mathrm{mg}$ methylene blue $/ \mathrm{kg}$ body weight in tissue of the rat vs. dose of methylene blue in $\mathrm{mg} / \mathrm{kg}$. Data of DiSanto and Wagner (57) presented differently than in original paper. 
Journal of Pharmacology in the future. Figures 4 and 5 illustrate a small amount of the data collected. In Fig. 4, the brain concentration of diphenhydramine is plotted as a function of dose administered. Each point represents a separate rat. Only the 1-min and $2-$ hr data have been plotted. Figure 5 shows the lung (at the top) and heart (at the bottom) concentration data as a function of dose. It is noteworthy that these data show the nonlinear asymptotic curvature analogous to the curves generated with the simulation example shown in Fig. 2.

Methylene blue is completely ionized at physiological $p \mathrm{H}$ values and hence is analogous to a quaternary ammonium compound. Diphenhydramine is a typical weakly basic amine. Both of these drugs were taken up by tissues extremely rapidly; with diphenhydramine, the tissue concentration measured $1 \mathrm{~min}$ after injection was usually the highest concentration observed. With methylene blue, an average of $27 \%$ of the dose (range $20-32 \%$ ) was accounted for in only four tissues (liver, kidney, heart, and lung) 3 min after the intravenous dose. Currently Theodore Benya, one of my graduate students, is studying the tissue distribution of warfarin, an acidic drug, in the rat. The same picture is emerging. After intravenous injection, the

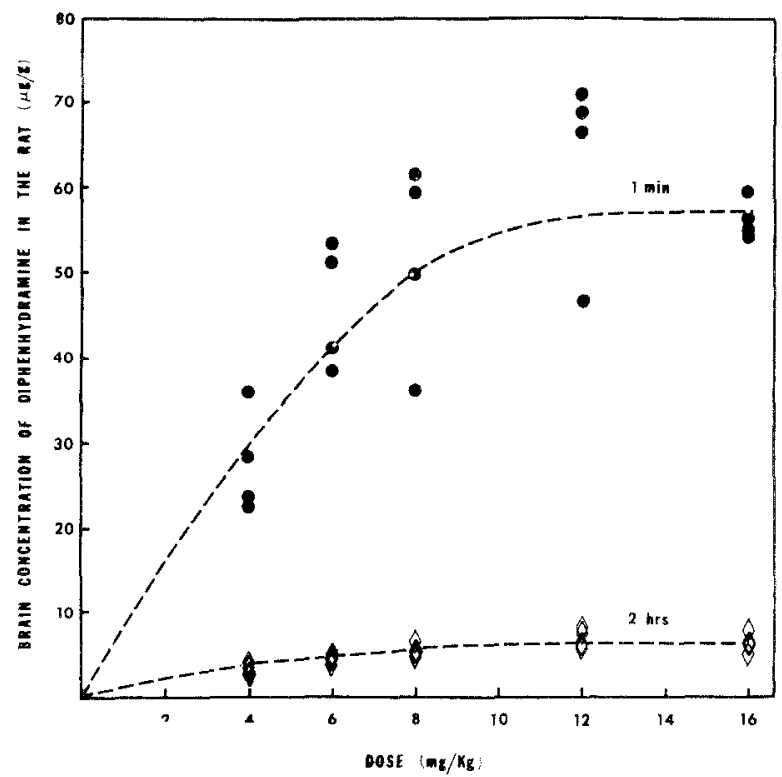

Fig. 4. Plot of brain concentration of dipherhydramine in the $\mathrm{rat}(\mu \mathrm{g} / \mathrm{g})$ vs. dose of diphenhydramine in $\mathrm{mg} / \mathrm{kg}$ administered by rapid intravenous injection. Upper curve $1 \mathrm{~min}$, and lower curve $2 \mathrm{hr}$ after injection. Data generated by Dr. Robert $\mathrm{N}$. Smith. 

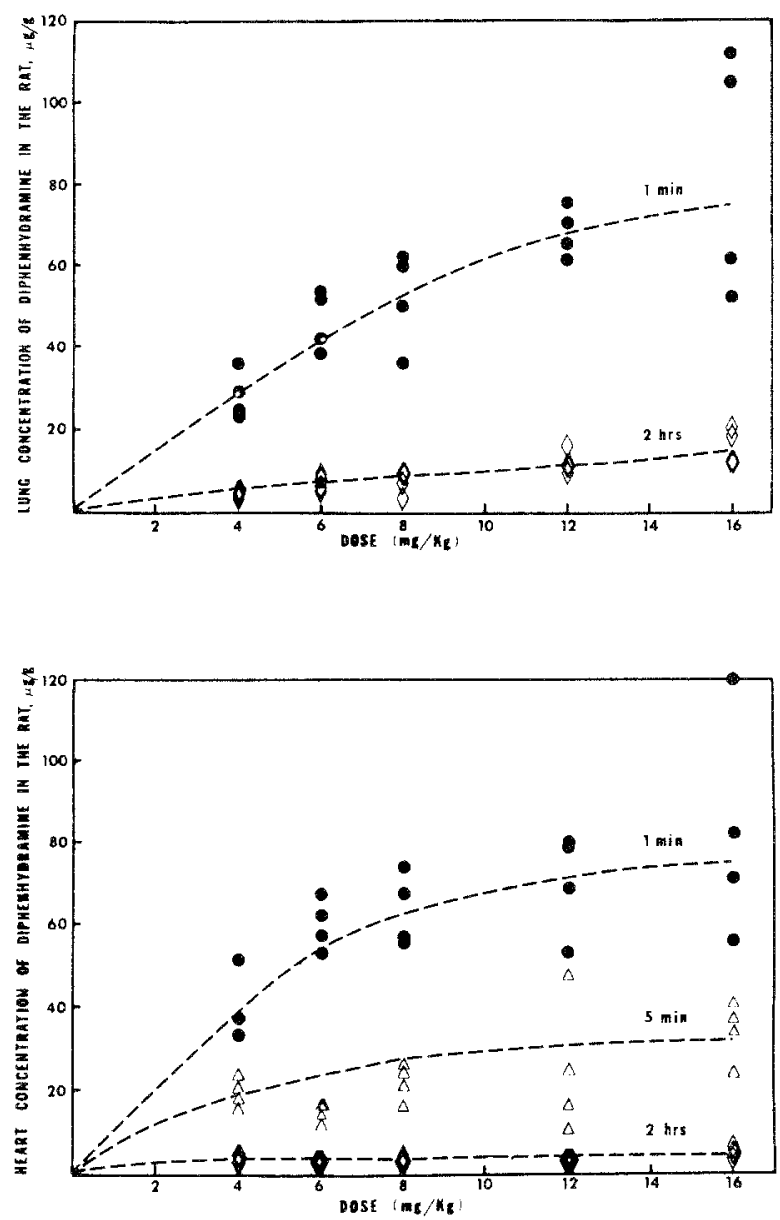

Fig. 5. Plot of lung concentration (upper half) and heart concentration (lower half) of diphenhydramine in the rat $(\mu \mathrm{g} / \mathrm{g})$ vs. dose of diphenhydramine in $\mathrm{mg} / \mathrm{kg}$ administered by rapid intravenous injection. Data generated by Dr. Robert N. Smith.

uptake of warfarin in tissues is extremely rapid and the disappearance exceedingly slow. The general picture emerging from these studies is that tissue uptake of drug is extremely rapid - much more rapid than one would usually predict from two-compartment analysis-and liberation of the tissue-bound drug is a slow process. Kinetic nonlinearity is very evident. The often repeated statement that highly plasma protein-bound drugs do not get into tissues is apparently incorrect since warfarin is about $97 \%$ bound to plasma proteins. 


\section{A CURRENT AND FUTURE PROBLEM IN PHARMACOKINETICS}

It is exceedingly difficult, if not impossible, to determine if a given set of whole blood, plasma, or serum concentrations of a drug measured after one dose is best described by a classical linear or nonlinear mathematical model. The problem is even more difficult with urinary data. Obtaining data after only one or two doses of a drug is usually insufficient to deduce the appropriate model. It is feasible for known nonlinear data to appear to be linear pharmacokinetic data when only one dose of a drug is studied. This is so even when the drug is administered by rapid intravenous injection. This concept is illustrated by two simulations below.

\section{Example I}

The data points in Fig. 6 obey equation 3 and were generated both by numerical integration of equation 2 and by use of equation 3 and a digital computer. The points in the concentration range $10-0.05 \mu \mathrm{g} / \mathrm{ml}$ and in the time range $0-9 \mathrm{hr}$ were fitted essentially perfectly by the equations appropriate to the classical two-compartment open model shown as equations 5 and 6 .

The solid line through the points

$$
\begin{gathered}
C=\left[C_{0} /(\alpha-\beta)\right]\left[\left(k_{21}-\beta\right) e^{-\beta t}-\left(k_{21}-\alpha\right) e^{-\alpha t}\right] \\
\alpha, \beta=\frac{1}{2}\left[\left(k_{12}+k_{21}+k_{e 1}\right) \pm \sqrt{\left.\left(k_{12}+k_{21}+k_{e 1}\right)^{2}-4 k_{21} k_{e 1}\right]}\right. \\
\text { where } \alpha>\beta
\end{gathered}
$$

in the indicated ranges are the model-predicted concentrations for the twocompartment open model. The dotted line in the figure is the extrapolated two-compartment model prediction. The points deviate from the line beyond $9 \mathrm{hr}$. However, if these were real data, and if one only had an assay sensitive to $0.05 \mu \mathrm{g} / \mathrm{ml}$, then one could not decide on these basis of these data only whether equation 3 or equations 5 and 6 were the appropriate mathematical model. This example was published by DiSanto and Wagner (148). If data were available from several simulations with different $C_{0}$ values (or real data were available following administration of several different doses), then a distinction between linear and nonlinear pharmacokinetics could be made.

\section{Example 2}

The data points for curve A of Fig. 7 are the same as those in Example 1 and Fig. 6. However, in Fig. 7 the least-squares $\log C t$ line was drawn through the points in the 5- to 9-hr time region. The dotted line indicates the extrapolation of the least-squares line. Hence only terminal points, in somewhat less than one log cycle, were linear on the semilogarithmic graph paper. The data points for curve B of Fig. 7 were obtained by numerical integration of 
equation 7 and hence obey the integrated form of equation 7 , namely equation 8 :

$$
\begin{aligned}
& d C / d t=\left[-V_{m} C /\left(K_{m}+C\right)\right] /\left[1+A B /(B+C)^{2}\right] \\
t= & \frac{C_{0}-C}{V_{m}}\left[1+\frac{A\left(B-K_{m}\right)}{(B+C)\left(B+C_{0}\right)}\right]+\frac{K_{m}}{V_{m}}\left[\left\{1+\frac{A}{B}\right\} \ln \frac{C_{0}}{C}\right. \\
+ & \left.\frac{A}{B} \ln \left\{\frac{B+C}{B+C_{0}}\right\}\right]
\end{aligned}
$$

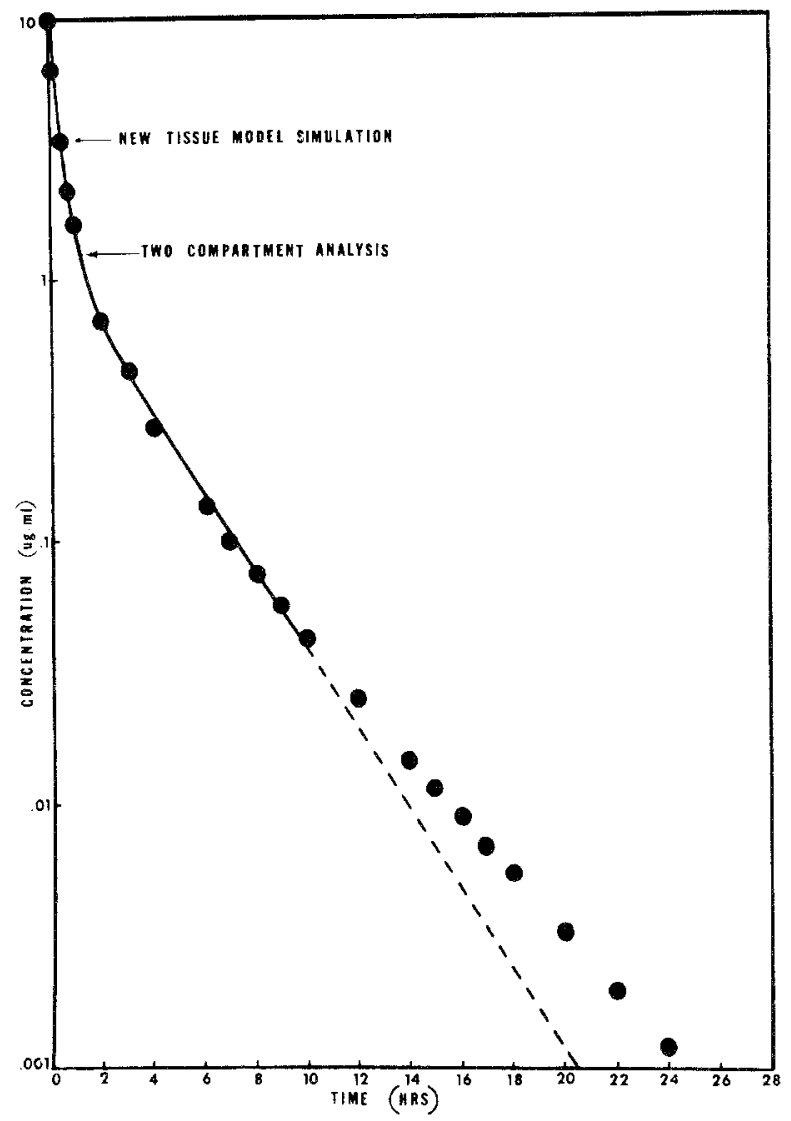

Fig. 6. Solid points are data simulated with equation 3. Solid line is from least-squares fit of 0 - to 9 -hr points to equations 5 and 6 , based on the two-compartment open model. The following values were used in the simulation: $C_{0}=10, B=1.0, A=$ $10 \mu \mathrm{g} / \mathrm{ml}, K=2.75 \mathrm{hr}^{-1}$, and $V=0.5 \mathrm{l} / \mathrm{kg}$. Dotted line indicates extrapolation according to the two compartment analysis. From DiSanto and Wagner (148) with permission of copyright owner. 


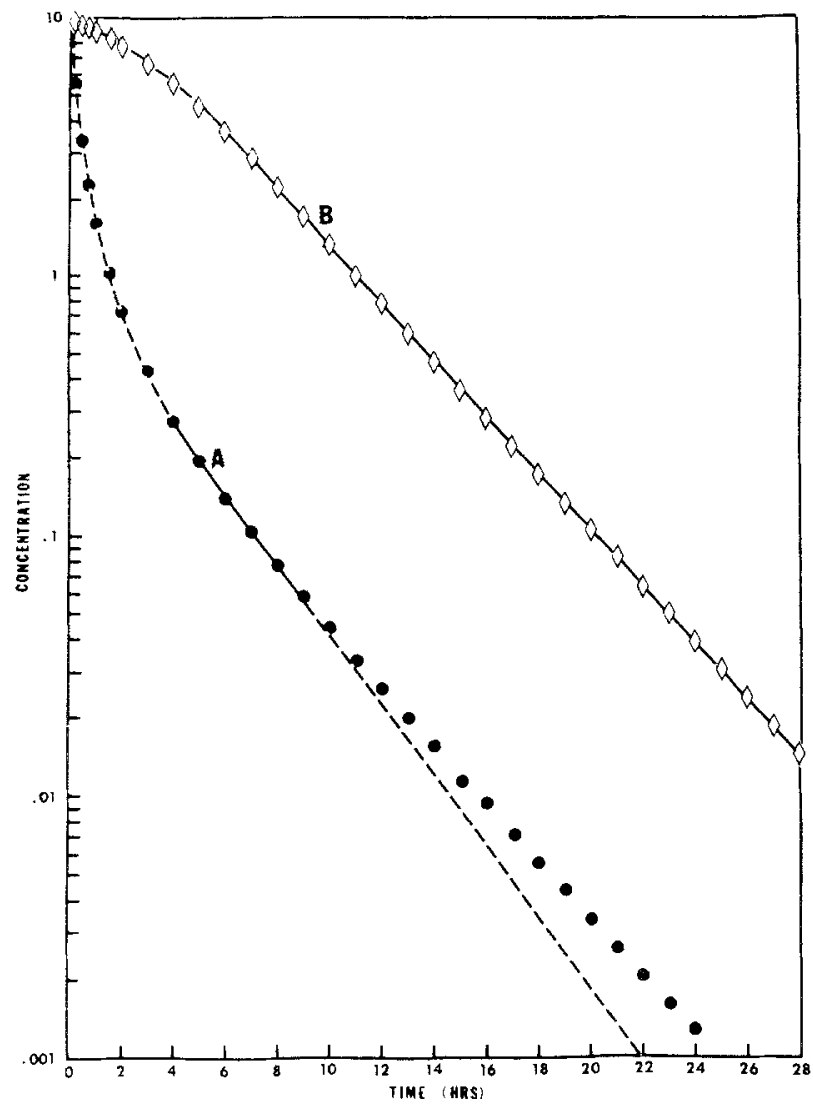

Fig. 7. Solid points are data simulated with equation 3 and are same points as in Fig. 6. Solid line is least-squares $\log C, t$ line based on 5- to 9-hr points and lower dotted line is extrapolation of this line. Open points were simulated with equation 8 using $V_{m}=1.375, K_{m}=0.5, A=10, B=1$, and $C_{0}=10$. Line drawn through the points from 5 to $28 \mathrm{hr}$ is the least-squares $\log C, t$ line indicating apparent first-order elimination, yet data were really generated from a model involving Michaelis-Menten kinetics and Langmuir-type tissue binding.

The line drawn through the data points from 5 to $28 \mathrm{hr}$ is the least-squares $\log C, t$ line and suggests simple first-order elimination. Yet the equation from which the data points were derived involved a model with MichaelisMenten elimination kinetics and Langmuir-type binding of drug to tissues. The particular set of parameter values used in the simulation were $V_{m}=1.375$, $K_{m}=0.5, A=10, B=1$, and $C_{0}=10$. Michaelis-Menten kinetics alone causes concave decreasing curvature when the $C, t$ data are plotted on semi- 
logarithmic graph paper. Langmuir-type tissue binding causes convex decreasing curvature when the $C, t$ data are plotted on semilogarithmic graph paper. A judicious mixture of Michaelis-Menten elimination kinetics and Langmuir-type tissue binding (i.e., the parameters are in a certain "space") yields the result shown as line B in Fig. 7. In a modern view of pharmacokinetics, we must be aware that such things can happen and, perhaps, not be as sure as we have in the past that fitting data to a model proves that the model is correct.

Three "real-world" examples along the same lines will be discussed.

\section{Salicylate}

As indicated in Table III, Schachter and Manis (69) published evidence of saturation effects in the formation and active tubular secretion of salicylurate and salicyl phenolic glucuronide from salicylate following an oral dose of $4 \mathrm{~g}$ of sodium salicylate in man. They also reported evidence of active tubular secretion of salicylate and salicyl acyl glucuronide. During the period 1965-1972, Dr. Levy, who is with us today, intensively studied the aspirin-salicylate problem (see citations in Table III under salicylic acid). He tackled the problem many ways and has certainly shown, at least to my satisfaction, that one must use Michaelis--Menten kinetics to elucidate the formation of salicylurate and salicyl phenolic glucuronide from salicylate. Rowland and Riegelman (149) and Rowland et al. (150) evaluated the pharmacokinetics of acetylsalicylic acid in man following intravenous administration by means of the classical two-compartment model for a drug and its metabolite. Wagner (151) showed that approximately $50 \%$ of a metabolite excreted in the urine may be excreted at such rates that the cumulative urinary excretion plot would appear to be nearly linear when the model is a catenary chain with parallel paths involving only first-order rate constants. In a review as late as 1968 , Wagner (152) supported the firstorder elimination kinetics of salicylate. However, currently I agree with Dr. Levy's interpretation. It was undoubtedly Dr. Levy's and Dr. KrügerThiemer's papers which first stimulated my interest in nonlinear pharmacokinetics. I am sure we have all learned a great deal from the saga of salicylate. In case the point is lost, I wish to reiterate that individual sets of nonlinear data can be fitted by linear pharmacokinetic equations and therein lies the real problem.

\section{Diphenylhydantoin}

Dayton et al. (92) published data which indicated that the elimination half-life of diphenylhydantoin in the dog apparently increased when the dose was raised from 20 to $50 \mathrm{mg} / \mathrm{kg}$. Analysis of diphenylhydantoin plasma 
concentration data, obtained following intravenous administration to man, by Suzuki et al. (103) and Blum et al. (104) indicated that dose-dependent kinetics did not occur. Plasma concentration data obtained following oral administration of diphenylhydantoin to man, published by Arnold and Gerber (105), indicated that dose-dependent kinetics did occur. Studies in mice (106) and in rats (107) also indicated marked nonlinearity. Recently, Gerber and Wagner (108) fitted sets of diphenylhydantoin plasma concentration data in man, and whole blood diphenylhydantoin concentration data in the rat, to the integrated form of the Michaelis-Menten equation:

$$
C_{0}-C+K_{m} \ln \left(C_{0} / C\right)=V_{m} t
$$

Although evaluated by the authors according to first-order kinetics, the diphenylhydantoin plasma concentration data of Glazko et al. (102) exhibit concave decreasing curvature on semilogarithmic graph paper, as expected for Michaelis-Menten kinetics. Based on the data published by Suzuki et al. (103) and Blum et al. (104), I, personally, would accept them as conventional two-compartment open model data. However, the data I evaluated with Dr. Gerber obviously are fitted very well by equation 9 . I have no further explanation of the discrepancy in the observed data at the present time.

\section{Riboflavin in the Rat}

Axelson and Gibaldi (133) discussed an unusual example of nonlinear pharmacokinetics. Estimation of the availability of riboflavin-5'-phosphate after oral administration to the rat is greatly complicated because of the occurrence of a complex and markedly nonlinear dose-dependent excretion of the vitamin. The elimination of the vitamin involves at least two nonlinear processes occurring simultaneously and having opposite effects on the dose-total urinary recovery relationship. One process involves biliary excretion which increases disproportionately with increasing body levels of riboflavin. The other process appears to be a binding of the vitamin to tissues which function kinetically as deep compartments. Apparently, the higher the body level of the vitamin, the smaller the fraction that can be "immobililized" in the compartment and the larger the fraction that can be detected in the urine. The latter is another way of stating in words what is implied by equation 4.

\section{Recognition of Nonlinearities}

1. Administer the drug intravenously at several different doses and obtain whole blood or plasma concentrations as a function of time. The entire curve must be defined including samples as early as 1 and 3 min after injection. Estimate the $C_{0}$ value of each curve by fitting the equation $\ln C=$ 
$\ln C_{0}-K t$ to only the first two points of each set of data. Calculate the values of the ratios $C / C_{0}$ and plot vs. time. Put all sets for all doses on the same piece of semilogarithmic graph paper. If each set forms its own curve and the data are not superimposable, then some type of nonlinearity exists. If the curves are superimposable, then the data are linear.

2. Fit each set of data (one dose per set) to the equations appropriate to the two-compartment open model, i.e., equations 5 and 6 . If the estimated parameters change in a uniform manner with dose, then this is a strong evidence of a nonlinear system.

3. If drug is administered orally or intramuscularly, then divide each plasma concentration by the dose, or the normalized dose, and plot the ratios vs. time. If the curves are not superimposable, then some type of nonlinearity exists.

4. Measure tissue concentrations of unchanged drug as a function of both time and dose. If one obtains curves such as shown at the bottom of Fig. 2 and in Figs. 3 and 5, then nonlinear tissue binding exists.

5. Administer a metabolizable drug in a readily available form such as an aqueous solution at several dose levels. Collect the urine until essentially all of the metabolite(s) is excreted. Plot the amount of each metabolite excreted as a percentage of the total urinary excretion against the dose. If the percentage decreases uniformly as the dose increases, then Michaelis-Menten kinetics should be suspected.

6. Administer the drug on a multiple dose regimen at several dose levels, establish an equilibrium state, then measure the metabolite concentration in the whole blood or plasma in a dosage interval at the equilibrium state. If the areas under the metabolite concentration curves at the equilibrium state are not a linear function of dose, but rather a curvilinear function of dose, then this is excellent evidence for the operation of Michaelis-Menten kinetics in the formation of the metabolite. One must be careful to insure that excretion is rate-limited by formation of the metabolite and that one is not dealing with a case such as acetaminophen, where the formation step of conjugation proceeds much more rapidly than the subsequent excretion step (124).

\section{NONLINEAR MODELS AND THE FITTING OF DATA}

\section{Plasma Protein Binding}

The effects of plasma protein binding of drugs on drug distribution and elimination are still controversial. One type of deviation from first-order elimination kinetics from the human body is characterized by a diminishing steepness of the slope of the total plasma concentration vs. time curve on 
semilogarithmic graph paper (i.e., convex decreasing curvature). This type of deviation exists for some sulfonamides which show a high degree of binding to plasma proteins and was discussed and referenced by Krüger-Thiemer (4). The higher the affinity for protein binding, the greater will be the bending of the log concentration vs. time curve. This is just the opposite behavior to that Martin(153) predicted from a judgment of the same problem. Krüger-Thiemer (4) published a mathematical model which could explain such deviations. In the conclusion of a review on the binding of drugs by plasma proteins, Meyer and Guttman (154) stated:

An impression, gained from the literature, is that there appears to be a tendency to overemphasize the general importance of the binding phenomenon in the behavior of drugs in the body. Evidence exists that only in the case of highly bound agents will binding be important in a practical sense. Many workers, in attempting to extrapolate in vitro data to in vivo expectations, tend to lose sight of the fact that the plasma comprises a relatively small fraction of the total volume available for drug distribution and that protein-drug complexes of rather extraordinary stability must be formed to substantially reduce the amount of drug that exists in the body in the active, diffusible, unbound form. A number of important drugs do, however, fall in the category of "strongly bound" and these serve as examples which emphasize the need to at least consider protein binding as a necessary parameter in the characterization of drug behavior.

Coffey et al. (155) described numerical methods for the solution of differential equations arising from nonlinear binding of drugs to plasma proteins, assuming one- and two-compartment pharmacokinetic models. The results suggested that binding of drugs to plasma proteins should cause detectable nonlinearity in the $\log C$ vs. $t$ plot only if doses are sufficiently high to approach saturation of binding sites, or if the number of binding sites in plasma is small. The effect of competition for binding sites in plasma was also studied by the same authors. They reported: "It appears that, unless the tissue distribution volume is quite small, competition for binding sites would not be expected to have a large effect." Curry (156) also studied this problem, but his results are discussed under tissue binding.

During his lifetime, Dr. E. Krüger-Thiemer contributed a great deal to pharmacokinetics. Only a few of his many papers are cited in this review $(4,140,141,157)$, but the cited papers contain many references to his work. He was mainly concerned with the problem of accumulation of drugs, the pharmacokinetics of suitable dosage requirements for individual patients, and the establishment of sufficient plasma concentration of free (unbound) drug, once the parameters of binding of the specific drug to plasma proteins were known. He developed and applied many mathematical models to reach these objectives. He developed many digital computer programs to allow the fitting of observed data to a specific mathematical model.

For a $70-\mathrm{kg}$ man, total plasma albumin is about $120 \mathrm{~g}$ and total interstitial albumin is about $156 \mathrm{~g}(158)$. Hence total body albumin is about 
$0.276 \mathrm{~kg}$ or about $0.4 \%$ of body weight. If total body water is taken as $60 \%$ of body weight, the "total tissue" expressed as dry weight is $28 \mathrm{~kg}$ or $40 \%$ of body weight. Thus the ratio of total dry tissue mass to total albumin mass is about $100: 1$. Since there are about 70 cardiac passes of blood per minute, and the dissociation of plasma protein-drug complexes, where it has been measured, is an exceeding rapid process, with a half-life of the order of 20 mseconds (159), it is not difficult to see that in most cases the binding of drugs to tissues will be kinetically much more important than the binding of drugs to albumin. This was pointed out also by Gillette (160). It is perhaps fortuitous, but Wiegand and Chun (58), after studying the serum protein and tissue binding of erythromycin and erythromycin-2'-propionate ester, calculated that drug bound to serum proteins is only about $1 \%$ of the dose and that most of the drug is bound to tissues.

\section{Tissue Binding}

In the light of the discussion above, it is amazing that so little experimental investigation has been conducted on the measurement of tissue concentrations of drug as a function of both time and dose. Most "distribution" data of specific drugs in animals and man have resulted from measurement of tissue concentrations at only one or two times after administration and usually following only one specific dose of drug. Such data give no insight into the kinetics of drug distribution. Recently, some investigators have measured tissue and plasma or whole blood concentrations as a function of tissue and dose. Drs. Bischoff and Dedrick, who reviewed other topics during this conference, have reported such data and developed pharmacokinetic models to explain such data. Dedrick and Bischoff (161) discussed pharmacokinetics in application to the artificial kidney; Bischoff and Dedrick (49) described thiopental pharmacokinetics; Zaharko et al. (40) reported on time- and dosedependent tissue concentrations of methotrexate; and Bischoff et al. $(41,162)$ described methotrexate pharmacokinetics. Dr. Bischoff won the 1972 Ebert Prize for his 1971 article "Methotrexate Pharmacokinetics," which was published in the Journal of Pharmaceutical Sciences (41). The flow-ratelimited model, described in that paper, incorporated compartments for the gastrointestinal tract, the liver and enterohepatic circulation, plasma, kidney, and muscle. Three compartments in series were used to simulate bile formation and secretion time in the liver. Transit of drug down the gastrointestinal tract was handled similarly, except that provision was made for transport through the intestinal wall. Tissue binding was assumed to be the sum of a linear nonspecific binding and a strong binding, presumed to be associated with dihydrofolate reductase, in conformity with equation 10 :

$$
C_{\text {tissue }}=R \cdot C p+(a \cdot C p) /(\varepsilon+C p)
$$


The model predicted the time courses of methotrexate in luminal contents of small intestine, liver, kidney, muscle, and plasma of mice, rats, and dogs with reasonable accuracy. As part of the model for thiopental pharmacokinetics, Bischoff and Dedrick (49) used two-term equations, such as equation 11, to estimate the bound concentration, $x$, of thiopental in tissues and in plasma:

$$
x=B_{1} K_{1} C /\left(1+K_{1} C\right)+B_{2} K_{2} C /\left(1+K_{2} C\right)
$$

In equation $11, C$ represents the free (unbound) concentration of drug.

Curry (156) reported that concentrations of chlorpromazine fluctuate in the plasma of dogs and man after intravenous doses. He examined the possibility that the fluctuations could arise from movement of the drug between tissue and plasma stores by performing simulations. His calculations showed that small changes in protein binding of drugs in plasma and tissues could cause redistribution of highly bound drugs between tissues and plasma. Also, redistribution would be greatest after changes in tissue binding of highly bound drugs. He hypothesized that fluctuations in chlorpromazine plasma concentrations could be caused this way.

A generalized nonlinear pharmacokinetic model was elaborated by DiSanto (163) and Wagner (147). The model takes into account the nonlinear tissue binding of drug to one or more tissues associated with one or more fluid compartments. Dose-dependent metabolism or urinary excretion may be incorporated into the generalized model by replacing the first-order elimination constant by an expression of the Michaelis-Menten type. Several specific applications of the general theory were discussed. The chapter (147) contains 126 equations, hence is too extensive to be reviewed here. Equations 2 and 3 , above, result from the simplest specific application of the generalized model and were employed by DiSanto and Wagner (148) in simulations and by DiSanto and Wagner (125) in interpreting whole blood concentrations obtained following rapid intravenous injection of five different doses of methylene blue in a dog. Figure 8 shows the results of a simultaneous fit of the whole blood concentration data, obtained following the five different doses of methylene blue, to equation 3 ; only one value of each of the parameters $A, B$, and $K$ and five different $C_{0}$ values were estimated during the digital computer fitting with Dr. Metzler's program NONLIN, modified by addition of a rootfinder subroutine. It is feasible that such an approach, with the same or alternate mathematical models, may yield valuable information for studies in comparative pharmacology. In such a case, the number of parameters estimated is small, and comparison of the values obtained from one species of animal to another with those estimated from human data may be a useful clue as to the appropriate species of animal for long-term toxicological studies. 


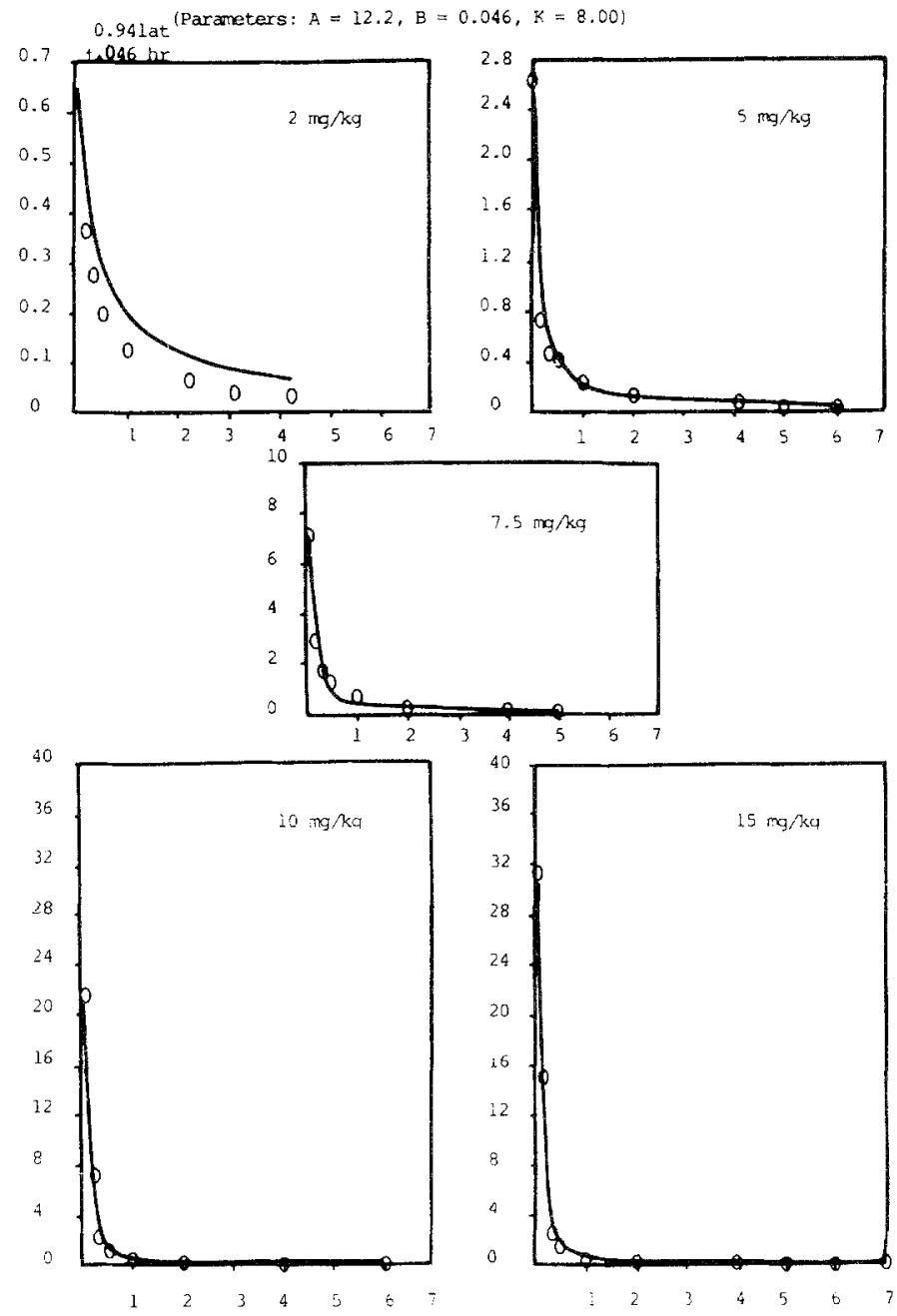

Fig. 8. Results of simultaneous nonlinear least-squares fitting of five sets of methylene blue whole blood concentrations to equation 3. Data from DiSanto and Wagner (57).

\section{Metabolism}

Lundquist and Wolthers (67) were the first to use the integrated form of the Michaelis-Menten equation, shown as equation 9, to explain blood concentration data. They fitted terminal serum concentrations of ethyl alcohol in man to the equation. The parameters, $K_{m}, V_{m}$, and $C_{0}$ for the fitting were obtained by graphic methods. The differential form, that is, the 
Michaelis-Menten equation itself, was used by Bischoff, Dedrick, and coworkers in their thiopental (49) and methotrexate (41) pharmacokinetic models. Levy et al. (80) simulated the time courses of the urinary excretion rate of total salicylic acid and metabolites, salicyluric acid, salicyl acyl glucuronide, salicyl phenolic glucuronide, gentisic acid, and salicylic acid in four subjects following a 3-g oral dose of salicylic acid as sodium salicylate in aqueous solution. In order to do this, it was necessary to determine the values of 14 individually determined constants (79). The formidable technical effort required an average of over 400 analyses per dose per subject. The constants estimated following the 3-g dose allowed excellent predictions following 1- and 0.19-g doses. The model equations employed involved Michaelis-Menten equations for the formation of salicylurate and salicyl phenolic glucuronide and first-order equations for formation of salicyl acyl glucuronide and gentisic acid and for excretion of unchanged salicylic acid and its absorption from the gut.

Figure 9 is taken from the paper of Wagner and Patel (9). The points are whole capillary blood ethanol concentrations measured in the same subject at different times. Two of the curves resulted from $60-\mathrm{ml}$, two of the curves resulted from $30-\mathrm{ml}$, and one curve resulted from $15-\mathrm{ml}$ oral doses of $95 \%$ ethyl alcohol. The solid lines drawn through the terminal points are the model-predicted values, based on fitting to equation 9 by numerically integrating the Michaelis-Menten equation on the digital computer and the assignment of equal weights. It was found in this study that the absorption rate of ethanol, and the values of $K_{m}$ and $V_{m}$, varied widely in the same subject and apparently in a random manner not related to dose or time of administration.

Figure 10 is taken from the paper of Gerber and Wagner (108). It shows the fit of plasma concentrations of diphenylhydantoin in a human subject to equation 9. The data were collected starting $12 \mathrm{hr}$ after the last dose when doses of $2.3,4.7$, and $7.9 \mathrm{mg} / \mathrm{kg}$ of sodium diphenylhydantoin (as Dilantin) were administered daily for 3 days during different time periods. The $V_{m}$ value estimated was $0.253 \mu \mathrm{g} /(\mathrm{ml} \times \mathrm{hr})$ and the $K_{m}$ value estimated was $7.77 \mu \mathrm{g} / \mathrm{ml}$.

Krüger-Thiemer and Levine (141) discussed several non-first-order models of drug metabolism including one which incorporated both capacity limitation and restricted availability of substrate.

\section{Miscellaneous Causes of Nonlinearities}

As summarized in Tables I, IV, and V, nonlinearities can result in drug absorption, in active tubular secretion and reabsorption in the kidney, and in biliary excretion of drugs and their metabolites. Circadian rhythm in 


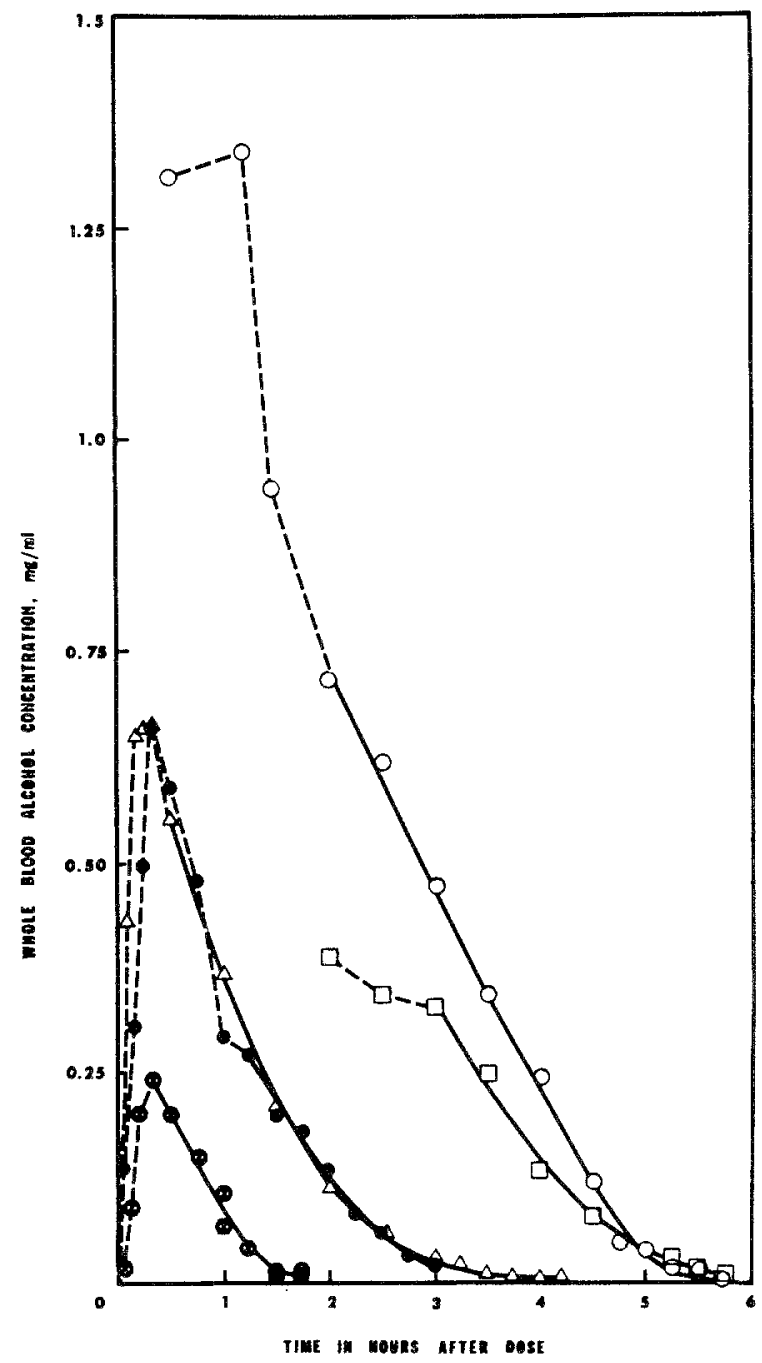

Fig. 9. Whole blood concentrations in a single subject at different times. Doses were $15 \mathrm{ml}(\otimes), 30 \mathrm{ml}(\triangle$ and $\bullet)$, and $60 \mathrm{ml}(\mathrm{O}$ and $\square)$ of $95 \%$ ethanol. Solid lines are leastsquares fits of terminal concentrations to equation 9. From Wagner and Patel (9).

hepatic drug-metabolizing enzyme activity, as discussed by Civen et al. (164) and Radzialowski and Bousquet (165), will undoubtedly cause nonlinearites even though we may not be able to "see" them readily. Enzyme stimulation and inhibition (166) may also cause nonlinearities. 


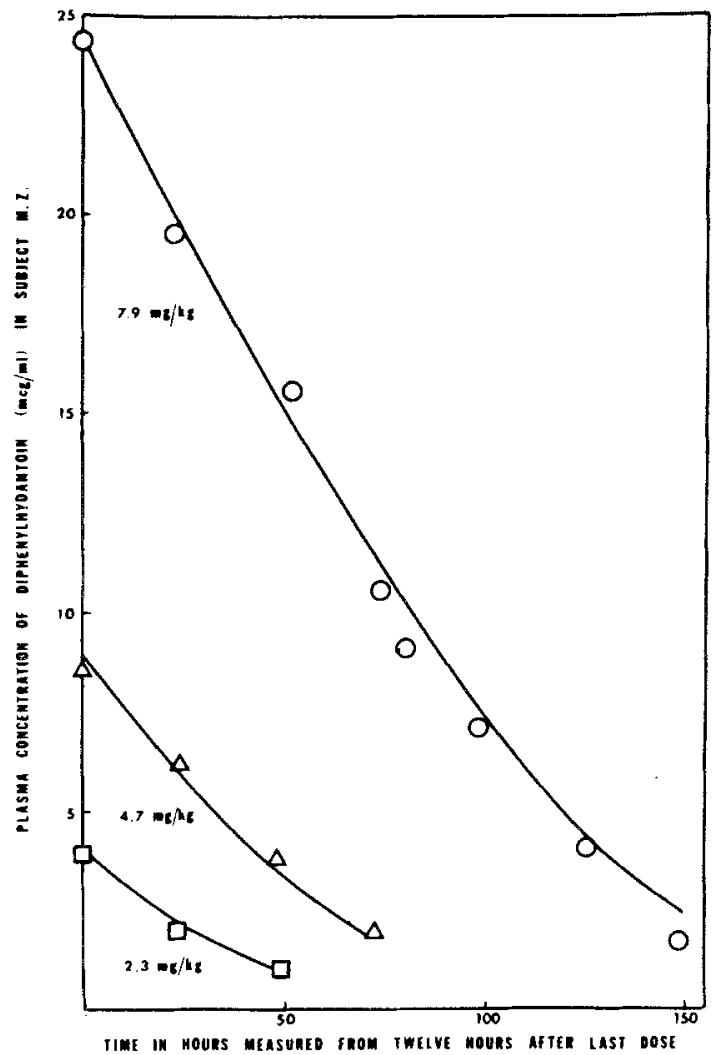

Fig. 10. Plasma diphenylhydantoin concentrations in a single subject at different times fitted to equation 9. "Zero time" is $12 \mathrm{hr}$ after the last of multiple doses of $2.3,4.7$, and $7.9 \mathrm{mg} / \mathrm{kg}$ of diphenylhydantoin sodium. From Gerber and Wagner (108) with permission of the copyright owner.

\section{Data Fitting Aids}

The fitting shown in Fig. 10 was achieved by successive trials of numerical integration of the Michaelis-Menten equation by the Runge-Kutta method using a simple electronic calculator. This is analogous to the use of an analog computer and suffers from the fact that no standard deviations of the estimated parameters, or other mathematical and statistical information, are obtained along with the fitting. Usually one uses a high-speed digital computer with a suitable nonlinear least-squares estimation program. Dr. Berman's SAAM program, Dr. Metzler's NONLIN, and Control Data's MIMIC are examples of successful programs which have been used widely for data-fitting and simulation purposes. Recently, Atkins $(167,168)$ described a 
new versatile digital computer program for nonlinear regression analysis. The iteration procedure used in this program possesses two important advantages over those used in the past, namely that second partial derivatives need not be calculated and convergence is guaranteed. Quasilinearization, discussed by Buell and Kalaba (169), may prove to be an aid in fitting of nonlinear models to experimental data.

\section{Pooling of Purallel Paths}

If there are parallel first-order paths in classical linear pharmacokinetics, one can simply add the first-order rate constants to obtain the overall elimination rate constant. But can we pool parallel Michaelis-Menten paths and parallel Langmuir-type tissue binding equations justifiably? About a year ago, I gave this problem to one of my graduate students, Allen J. Sedman, and at the meeting of the A.Ph.A. Academy of Pharmaceutical Sciences in April 1972 we presented a paper entitled "Quantitative Pooling of Both Parallel Michaelis-Menten Formation Equations and Langmuir-Type Equations for Binding of Drugs to Tissues" (170). In the paper, we answered the above question with a qualified "yes." Sedman developed equations which allowed calculation of the pooled parameters, $V_{m p}$ and $K_{m p}$, from the microscopic parameters $V_{m 1}, V_{m 2}, K_{m 1}$, and $K_{m 2}$ for parallel MichaelisMenten paths and also for the Langmuir-type equations. The simulated data could always be fitted essentially exactly using the calculated pooled parameters. When the parameters have a certain relationship to each other, there is no problem in the sense that the pooled parameters need not change in dose. In certain cases, which are usually predictable, the pooled parameters will change with change in dose. The simulations suggested the appropriate experimentation with a given drug. One should study as low a dose as one can measure adequately and as high a dose as one may give safely, and see if the nonlinear parameters appear to change with dose. If they do not, then one is reasonably safe with the pooling concept within that dose range with that drug. In this rapidly moving field, one is never alone. When we returned from the Houston meeting, we found the paper by Spears et al. (171) and the paper of Neal (172) which treated the same problem, but in a different way than we tackled it.

\section{SOME COMMENTS ABOUT MICHAELIS-MENTEN KINETICS}

In Wagner (109) and Wagner and Patel (9), the properties of the Michaelis-Menten equation and its integrated form are discussed extensively. We will not delve deeply into those papers at the present time. However, one or two points are worthy of special consideration. As one can see in 
Figs. 9 and 10, when equation 9 is obeyed (solid lines) there is initially an apparently linear segment and then a sharp break in the curve-the whole curve taking on a "hockey stick" shape. The apparently linear segment has often been assumed to be linear, because the assumption has been made that the enzyme is saturated. But this is a poor assumption because independent of the initial $C_{0}$ value the integrated form of the Michaelis-Menten equation always gives a pseudolinear portion over about two-thirds of the range or more. It is only pseudolinear since the derivative changes when the concentration changes, as evidenced by looking at the Michaelis-Menten equation itself. If one does assume that this pseudolinear segment is linear, and we symbolize the slope by $k_{0}$, then one can derive equation 12 :

$$
1 / k_{0}=1 / V_{m}+\left[K_{m} / 0.632 V_{m}\right] \times 1 / C_{0}
$$

Equation 12 indicates that if $V_{m}$ and $K_{m}$ remain constant, then a plot of the reciprocal of the slope of the pseudolinear portion will be linearly related to the reciprocal of the initial concentration or $C_{0}$ value. This shows why the classical concept of ethanol metabolism in man and animals is really incorrect. The apparently linear decline of alcohol blood levels will vary with the dose administered even if $K_{m}$ and $V_{m}$ remain constant, and the slope will also be a function of the volume of distribution and sometimes of the absorption rate. However, as stated previously, when five doses of ethanol were taken at different times the values of $K_{m}, V_{m}$, and $k_{0}$ varied widely. Hence the classical concept that alcohol in a given individual is eliminated at a fixed rate independent of its concentration in the body was not supported by our studies. Also, one the value of $K_{m}$ for the particular system is known, one can use equation 1 to calculate the percent saturation of the "enzyme system" at different $C$ values of interest.

\section{A CHECKLIST FOR POSSIBLE FUTURE PHARMACOKINETIC STUDIES}

From my reading and experimental investigations, certain guidelines have emerged:

1. Preferably do intensive sampling after intravenous administration of several (preferably five or six) doses in at least one species of animal. The data from such studies provide much more information, when only one or two rats or dogs are used per dose, than when five to ten rats or dogs are given with only one or two doses of a drug.

2. After rapid intravenous injection, take initial samples very early after injection, such as at 1,3,5 min. Continue sampling until assay sensitivity is reached following all doses. Much of the apparent dose-dependent "first- 
order" kinetics in the literature was caused by estimating the first-order rate constant in a different concentration region after each dose. Also, extremely rapid uptake of many drugs by tissues has been "missed" since the first tissue samples were taken at 1 or $2 \mathrm{hr}$ after injection.

3. Measure tissue levels as a function of both time and dose in at least one species of animal such as the rat. The rapid intravenous route of administration is preferred and sampling should be as discussed above.

4. After oral administration of many rapidly absorbed drugs, blood samples should be taken as early as $10-20$ min after administration in order to obtain data on the "up part" of the plasma or blood concentration curve. Some drugs are absorbed by passive diffusion extremely rapidly in fasting subjects. We have a distorted view since in most human studies the first blood sample has been taken $1 \mathrm{hr}$ or later after administration. Recently, we found that the first blood sample, taken at $20 \mathrm{~min}$ after oral administration of sodium $p$-aminosalicylate in an aqueous solution to a fasting human subject, gave the highest plasma concentration of PAS.

5. To check quickly for tissue saturation effects, by measuring only plasma levels, perform a "loading-dose" experiment. Give, say, $5 \mathrm{mg} / \mathrm{kg}$ of drug by rapid intravenous injection and measure plasma concentrations of unchanged drug at 1,5 , and $10 \mathrm{~min}$. Then give $10 \mathrm{mg} / \mathrm{kg}$, and $1 \mathrm{hr}$ later give $5 \mathrm{mg} / \mathrm{kg}$, and measure the plasma concentration again at 1,5 , and $10 \mathrm{~min}$ after the $5 \mathrm{mg} / \mathrm{kg}$ dose. If the plasma levels are appreciably higher in the loading-dose experiment, this constitutes good evidence of some saturation phenomenon and usually it will be saturable tissue binding. With some drugs, the cited doses obviously would have to be drastically altered.

6. Be sure the analytical method used is specific for the unchanged drug and one or more metabolites and that the method has good sensitivity and reproducibility. After intravenous administration, it is preferable to be able to measure drug concentrations through at least two and preferably three or more log cycles on semilogarithmic graph paper. After oral administration, the assay method should be sensitive enough to follow the drug levels down to at least one-tenth or one-twentieth of the peak concentration. Samples should be collected so that this criterion can be met after each treatment, if possible. The literature is replete with erroneous half-lives of drugs since plasma levels were not measured for a long enough period of time. In drug availability studies, the calculation of "bioavailability" from measurement of the area under only one-half or two-thirds of the plasma concentration curve is just plain misleading.

7. Estimate elimination half-lives after different doses are administered to the same subject or animal in the same concentration range, not necessarily in the same time range. 


\section{REFERENCES}

1. E. Widmark and J. Tandberg. Uber die Bedingungen fur die Akkumulation indifferenter narkoliken theoretische Bereckerunger. Biochem. Z. 147: 358-369 (1924).

2. T. Teorell. Kinetics of distribution of substances administered to the body. I. The extravascular modes of administration. Arch. Int. Pharmacodyn. 57: 205-225 (1937).

3. T. Teorell. Kinetics of distribution of substances administered to the body. II. The intravascular modes of administration. Arch. Int. Pharmacodyn. 57: 226-240 (1937).

4. E. Krüger-Thiemer. Nonlinear dose-concentration relationship. Il Farmao (Pavia) Ed. Sci. 23: $717-756$ (1968).

5. L. Z. Benet and J. S. Turi. Use of general partial fraction theorem for obtaining inverse Laplace transforms in pharmacokinetic analysis. J. Pharm. Sci. 60: 1593-1594 (1971).

6. L. Z. Benet. General treatment of linear mammillary models with elimination from any compartment as used in pharmacokinetics. J. Pharm. Sci. 61: 536-541 (1972).

7. E. Widmark. Verteilung und Umwandlung des Äthylalkohols im Organismus des Hundes. Biochem. Z. 267: 128-134 (1933).

8. E. Widmark. Der Einfiuss der Nahrungsbestandteile auf den Alkoholgehalt des Blutes. Biochem. Z. 267: 135-142 (1933).

9. J. G. Wagner and J. A. Patel. Variations in absorption and elimination rates of ethyl alcohol in a single subject. Res. Commun. Chem. Pathol. Pharm. 4: 61-76 (1972).

10. W. Wilbrandt and P. Rosenberg. The concept of carrier transport and its corollaries in pharmacology. Pharmacol. Rev. 13: 109-183 (1961).

11. C. S. Patlak. Contributions to the theory of active transport. III. The effect of drugs on active transport systems. Bull. Math. Biophys. 23: 173-195 (1961).

12. G. Levy and W. J. Jusko. Factors affecting the absorption of riboflavin in man. J. Pharm. Sci. 55: 285-289 (1966).

13. H. Ochsenfahrt and D. Winne. Intestinal blood flow and drug absorption from the rat jejunum. Life Sci. 7: 493-498 (1968).

14. M. Rowland, S. Riegelman, and W. L. Epstein. Absorption kinetics of griseofulvin in man. J. Pharm. Sci. 57: 984989 (1968).

15. G. W. Hepner, C. C. Booth, J. Cowan. A. V. Hoffbrand, and D. L. Mollin. Absorption of crystalline folic acid in man. Lancet, Aug. 10, pp. 302-306 (1968).

16. W. B. Strum, P. F. Nixon, H. J. Binder, and J. R. Bertino. Intestinal absorption of 5methyltetrahydrofolate (MTHF). Clin. Res. 18: 389 (1970) (abst.).

17. F. Lauterback. Comparison of intestinal penetration of cortisol and conuallatexin: Demonstration of a transport mechanism for cariotonic steroids. Biochim. Biophys. Acta 150: 146-155 (1968).

18. K. Kakemi, T. Arita, R. Hori, R. Konishi, and K. Nishimura. Absorption and excretion of drugs. XXXIII. The correlation between the absorption of barbituric acid derivatives from the rat small intestine and their binding to the mucosa. Chem. Pharm. Bull. (Tokyo) 17: 248-254 (1969).

19. A. Suzuki, W. I. Higuchi, and N. F. H. Ho. Theoretical model studies of drug absorption and transport in the gastrointestinal tract. I. J. Pharm. Sci. 59: 651-659 (1970).

20. W. Crouthamel, J. T. Doluisio, R. E. Johnson, and L. Diamond. Effect of mesenteric blood flow on intestinal drug absorption. J. Pharm. Sci. 59: 878-879 (1970).

21. D. Winne. Formal kinetics of water and solute absorption with regard to intestinal blood flow. J. Theoret. Biol. 27: 1-18 (1970).

22. P. Lauger and G. Stark. Kinetics of carrier-mediated ion transport across lipid bilayer membranes. Biochim. Biophys. Acta 211 : 458-466 (1970).

23. C. McMartin and P. Simpson. The absorption and metabolism of guanethidine in hypertensive patients requiring different doses of the drug. Clin. Pharmacol. Therap. 12: 73-77 (1971).

24. J. C. Dearden and E. Tomlinson. Buccal absorption as a parameter of analgesic activity of some p-substituted acetanilides. J. Pharm. Pharmacol. 23: 73S-76S (1971) (suppl.).

25. T. Fuwa, T. Iga, M. Nakano, H. Nogami, and K. Kashima. Biopharmaceutical studies on indomethacin. II. Mechanism of intestinal absorption of indomethacin in rat in vitro and 
availability of micronized powder after oral administration in man. J. Pharm. Soc. Japan 91: $1223-1227$ (1971).

26. R. B. Smith, L. W. Dittert, W. O. Griffen, Jr, and J. T. Doluisio. Pharmacokinetics of pentobarbital after intravenous and oral administration. J. Pharmacokin. Biopharm. 1: $5-16(1973)$.

27. J. G. Wagner and A. J. Sedman. Quantitation of rate of gastrointestinal and buccal absorption of acidic and basic drugs based on extraction theory. J. Pharmacokin. Biopharm. 1: $23-50$ (1973).

28. W. H. Barr and S. Riegelman. Intestinal drug absorption and metabolism. I. Comparison of methods and models to study physiological factors of in vitro and in vivo intestinal absorption. J. Pharm. Sci. 57:154-163 (1970).

29. W. H. Barr and S. Riegelman. Intestinal drug absorption and metabolism. II. Kinetic aspects of intestinal glucuronide conjugation. J. Pharm. Sci. 59: 164-168 (1970).

30. J. A. Jacquez, R. Bellman, and R. Kalaba. Some mathematical aspects of chemotherapy. II. The distribution of a drug in the body. Bull. Math. Biophys. 22: 309-322 (1960).

31. L. A. Carlson and D. Hallberg. Studies on the elimination of exogenous lipids from the blood stream. The kinetics of the elimination of a fat emulsion and of chylmicrones in the dog after a single injection. Acta. Physiol. Scand. 59: 52-61 (1963).

32. D. Hallberg. Studies on the elimination of exogenous lipids from the blood stream. The kinetics of the elimination of a fat emulsion studied by a constant infusion technique in man. Acta Physiol. Scand. 64: 299-305 (1965).

33. D. Hallberg. Studies on the elimination of exogenous lipids from the blood stream. The kinetics of the elimination of a fat emulsion studied by single injection technique in man. Acta Physiol. Scand. 64: 306-313 (1965).

34. E. Andersson, B. Norberg, and A. C. Teger-Nilsson. On the import of the clinical determination of the so-called hepatic mass (hm) with bromsulfalein. Scand. J. Clin. Lab. Invest. 15: 517-522 (1963).

35. C. A. Goresky. Initial distribution and rate of uptake of sulfobromophthalein in the liver. Am. J. Physiol. 207: 13-26 (1964).

36. K. Winkler and N. Tygstrup. The day-to-day variations in bromsulfalein elimination curves. Scand. J. Clin. Lab. Invest. 16:481-490 (1964).

37. B. H. Marks, S. Dutta, J. Gauthier, and D. Elliott. Distribution in plasma, uptake by the heart and excretion of ouabain- $\mathrm{H}^{3}$ in human subject. J. Pharmacol. Exptl. Therap. 1.45: 351-356 (1964).

38. L. S. Schanker and A. S. Morrison. Physiological disposition of guanethidine in the rat and its uptake by heart slices. Internat. J. Neuropharmacol. 4: 23-39 (1965).

39. E. S. Henderson, R. H. Adamson, C. Denham, and V. T. Oliverio. The metabolic fate of tritiated methotrexate. I. Absorption, excretion, and distribution in mice, rats, dogs and monkeys. Cancer Res. 25: 1008-1018 (1965).

40. D. S. Zaharko, R. L. Dedrick, and V. T. Oliverio. Time and dose dependent tissue concentration of methotrexate. Fed. Proc. 29: 932 (1970) (abst.).

41. K. G. Bischoff, R. L. Dedrick, D. S. Zaharko, and J. A. Longstreth. Methotrexate pharmacokinetics. J. Pharm. Sci. 60: 1128-1133 (1971).

42. H. Stupp, S. Ruck, H. Sous. J. P. Brun, and F. Legler. Kanamycin dosage and levels in ear and other organs. Arch. Otolaryngol. 86: 515-521 (1967).

43. S. D. Sholkoff, E. J. Eyering, M. Rowland, and S. Riegelman. Plasma and synovial fluid concentrations of acetylsalicyclic acid in patients with rheumatoid arthritis. Arth. Rheum. 10: $348-351$ (1967).

44. R. Nagashima, G. Levy, and E. Nelson. Comparative pharmacokinetics of coumarin anticoagulants. I. Unusual interaction of bishydroxycoumarin with plasma proteinsdevelopment of a new assay. J. Pharm. Sci. 57: 58-67 (1968).

45. R. Nagashima, G. Levy, and E. J. Sarcione. Comparative pharmacokinetics of coumarin anticoagulants. III. Factors affecting the distribution and elimination of bishydroxycoumarin (BHC) in isolated liver perfusion studies. J. Pharm. Sci. 57: 1881-1888 (1968).

46. R. Nagashima, G. Levy, and R. A. O'Reilly. Comparative pharmacokinetics of coumarin anticoagulants. IV. Application of a three-compartmental model to the analysis of the 
dose-dependent kinetics of bishydroxycoumarin elimination. J. Pharm. Sci. 57: 1888-1895 (1968).

47. G. Levy and R. Nagashima. Comparative pharmacokinetics of coumarin anticoagulants. VI. Effect of plasma protein binding on the distribution and elimination of bishydroxycoumarin by rats. J. Pharm. Sci. 58: 1001-1004 (1969).

48. W. H. Oldendorf. Dose-dependence of the rapid reappearance in blood of very small intravenous doses of $\mathrm{Se}^{75}$ Selenite. Internat. J. Appl. Radiation Isotopes 19:411-414 (1968).

49. K. B. Bischoff and R. L. Dedrick. Thiopental pharmacokinetics. J. Pharm. Sci. 57: 13471357 (1968)

50. R. L. Dixon, E. S. Owens, and D. P. Ral!. Evidence of active transplant of benzyl- ${ }^{14} \mathrm{C}-$ penicillin from cerebrospinal fluid to blood. J. Pharm. Sci. 58: 1 106-1109 (1969).

51. P. F. Binnion, L. M. Morgan, H. M. Stevenson, and E. Fletcher. Plasma and myocardial digoxin concentrations in patients on oral therapy. Brit. Heart J. 31: 636-640 (1969).

52. G. Paumgartner, P. Probst, R. Kraines, and C. M. Leevy. Kinetics of indocyanine green removal from the blood. Ann. N.Y. Acad. Sci. 170: 134-147 (1970).

53. J. C. Drach, J. P. Howell, P. E. Borony, and A. J. Glazko. Species differences in the metabolism of diphenhydramine (Benadryl). Proc, Soc. Exptl. Biol. Med. 135: 849-853 (1970).

54. E. D. Rees, P. Mandelstram, J. Q. Lowry, and H. Lipscomb. A study on the metabolism of intestinal absorption of benzopyrene (BBA 75555). Biochim. Biophys. Acta 225: 96-107 (1971).

55. J. J. Timmes, N. J. Demos, and S. I. Chong. Lung tissue and serum levels of methacycline. Clin. Pharmacol. Therap. 12: 920 -922 (1971).

56. A. R. DiSanto and J. G. Wagner. Pharmacokinetics of highly ionized drugs. I. Methylene blue-whole blood, urine and tissue assays. J. Pharm. Sci. 61: 598-602 (1972).

57. A. R. DiSanto and J. G. Wagner. Pharmacokinetics of highly ionized drugs. III. Methylene blue-blood levels in the dog and tissue levels in the rat following intravenous administration. J. Pharm. Sci. 61: 1090-1094 (1972).

58. R. G. Wiegand and A. H. C. Chun. Serum protein binding of erythromycin and erythromycin 2-propionate ester. J. Pharm. Sci. 61: 425-428 (1972).

59. D. S. Alberts, M. R. Bachur, and J. L. Holtzman. The pharmacokinetics of daunomycin in man. Clin. Pharmacol. Therap. 12: 96-104 (1971).

60. R. Nagashima and G. Levy. Effect of perfusion rate and distribution factors on drug elimination kinetics in a perfused organ system. J. Pharm. Sci. 57: 1991-1993 (1968).

61. J. B. Hill. The effect of altering blood $p \mathrm{H}$ on rat tissue and plasma salicylate concentrations. Fed. Proc. 29: 934 (1970) (abst.).

62. S. M. Somani, D. Schumacher, R. Thomson, and R. H. McDonald, Jr. Characterization of the distribution of secobarbital and its compartmental simulation. Fed. Proc. 30(2): 335 (1971) (abst.).

63. W. L. Chiou and S. Riegelman. Disposition kinetics of griseofulvin in dogs. J. Pharm. Sci. 58: 1500-1504 (1969).

64. L. E. Mather, G. J. Long, and J. T. Thomas. The intravenous toxicity and clearance of bupivacaine in man. Clin. Pharmacol. Therap. 12: 935-943 (1971).

65. M. Tomura and T. Akera. Relationship between dose and plateau levels of drugs eliminated by parallel first-order and capacity-limited kinetics. Jap. J. Pharmacol. 21: 682-685 (1971).

66. M. G. Eggleton. Some factors affecting the metabolic rate of alcohol. J. Physiol. (Lond.) 98: 239-254 (1940).

67. F. Lundquist and $\mathrm{H}$. Wolthers. The kinetics of alcohol elimination in man. Acta Pharmacol. Toxicol. 14: 265-289 (1958).

68. H. G. Bray, W. V. Thorpe. and K. White. Kinetic studies of the metabolism of foreign organic compounds. I. The formation of benzoic acid from benzamide, toluene, benzyl alcohol and benzaldehyde and its conjugation with glycine and glucuronic acid in the rabbit. Biochem. J. 48: 88-96 (1951).

69. D. Schachter and J. G. Manis. Salicylate and salicyl conjugates. Fluorimetric estimation. Biosynthesis and renal excretion in man. J. Clin. Invest. 37: 800-807 (1958). 
70. G. Levy. Salicylurate formation-Demonstration of Michaelis-Menten kinetics in man. J. Pharm. Sci. 54: 496 (1965).

71. G. Levy. Pharmacokinetics of salicylate elimination in man. J. Pharm. Sci. 54: 959-967 (1965).

72. E. Nelson, M. Hanano, and G. Levy. Comparative pharmacokinetics of salicylate elimination in man and rats. J. Pharmacol. Expll. Therap. 153: 159-166 (1966).

73. G. Levy. Dose-dependent effects in pharmacokinetics. In D. H. Tedeschi and R. E. Tedeschi (eds.), Importance of Fundamental Principles in Drug Evaluation, Raven Press, New York, 1968, pp. 141-172.

74. G. Levy and S. J. Yaffe. The study of salicylate pharmacokinetics in intoxicated infants and children. Clin. Toxicol. 1: 409-424 (1968).

75. G. Levy, L. P. Amsel, and H. C. Elliott. Kinetics of salicyluric acid elimination in man. J. Pharm. Sci. 58: 827-829 (1969).

76. G. Levy, A. W. Vogel, and L. P. Amsel. Capacity-limited salicylurate formation during prolonged administration of aspirin to healthy human subjects. J. Pharm. Sci. 58: 503-504 (1969).

77. G. Levy and H. Yamada. Estimation of drug metabolite elimination kinetics in man by the synthesis-blocking method. J. Pharm. Pharmacol. 22: 964-965 (1970).

78. G. Levy, L. Weintraub. T. Matsuzawa, and S. R. Oles. Absorption metabolism and excretion of salicyl phenolic glucuronide in rats. J. Pharm. Sci. 55: 1319-1320 (1966).

79. G. Levy. Saturation of glucuronide formation in man and its clinical implications. Chem. Biol. Interactions 3: 291 (1971).

80. G. Levy, T. Tsuchiya, and L. P. Amsel. Limited capacity for salicyl phenolic glucuronide formation and its effect on the kinetics of salicylate elimination in man. Clin. Pharmacol. Therap. 13: 258-268 (1972).

81. G. Levy and L. P. Amsel. Kinetics of competitive inhibitions of salicylic acid conjugation with glycine in man. Biochem. Pharmacol. 15: 1033-1038 (1966).

82. G. Levy and J. A. Procknal. Drug biotransformation interactions in man. I. Mutual inhibition in glucuronide formation of salicylic acid and salicylamide in man. J. Pharm. Sci. 57: 1330-1334 (1968).

83. L. P. Amsel and G. Levy. Drug transformation interactions in man. II. A pharmacokinetıc study of the simultaneous conjugatıon of benzoic and salicylic acids with glycine. J. Pharm. Sci. 58: 321-326 (1969).

84. P. Nordquist, J. G. Harthon, and R. Karlsson. Metabolic kinetics of salicylsalicylic acid, aspirin and sodium salicylate in man. Nord. Med. 74: 1024-1026 (1965).

85. G. Levy and T. Matsuzawa. Role of sulfate formation in biotransformation of salicylamide in man. J. Pharm. Sci. 55: 222-223 (1966).

86. G. Levy and T. Matsuzawa. Pharmacokinetics of salicylamide elimination in man. $J$. Pharmacol. Exptl. Therap, 156: 285-293 (1967).

87. W. H. Barr and S. Riegelman. Effect of capacity limited metabolism on plasma levels of free salicylamide in mart. Presented to APhA Academy of Pharmaceutical Sciences, May 6 , 1968, Miami Beach, Fla.

88. G. Levy and H. Yamada. Drug biotransformation interactions in man. III. Acetaminophen and salicylamide. J. Pharm. Sci. 60: 215-221 (1971).

89. G. Levy and G. C. Regardh. Drug biotransformation interactions in man. V. Acetaminophen and salicylic acid. J. Pharm. Sci. 60: 608-611 (1971).

90. K. Kakemi, T. Arita, H. Sezaki. and M. Nakano. Absorption and excretion of drugs. XVI. Inhibition of isoniazid acetylation by $p$-aminobenzaldehyde and its related compounds. J. Pharm. Soc. Japan 83: 260-263 (1963).

91. M. M. Drucker, S. H. Blondheim, and L. Wislicki. Factors affecting acetylation in vivo of para-aminobenzoic acid by human subjects. Clin. Sci. 26: 133-141 (1964).

92. P. G. Dayton, S. A. Cucinell, M. Weiss, and J. M. Perel. Dose-dependence of drug plasma level decline in dogs. J. Pharmacol. Exptl. Therap. 158: 305-316 (1967).

93. R. Nagashima, G. Levy, and N. Back. Comparative pharmacokinetics of coumarin anticoagulants. II. Pharmacokinetics of bishydroxycoumarin elimination in the rat, guinea pig, dog and rhesus monkey. J. Pharm. Sci. 57: 68-71 (1968). 
94. R. Nagashima and G. Levy. Comparative pharmacokinetics of coumarin anticoagulants. III. Factors affecting the distribution and elimination of bishydroxycoumarin (BHC) in isolated liver perfusion studies. J. F'arm. Sci. 58: 845-849 (1969).

95. J. G. Wagner and R. E. Damiano. Relationship among area under serum concentration curve, dose, and half-life for novobiocin administered in combination with tetracycline. J. Clin. Pharmacol. J. New Drugs 8: 102-112 (1968).

96. A. A. Kondritzer, P. Zvirblis, A. Goodman, and S. H. Paplanus. Blood plasma levels and elimination of salts in 2-PAM in man after oral administration. J. Pharm. Sci. 57: 1142$1146(1968)$.

97. F. R. Sidell, W. A. Groff, and R. I: Ellin. Blood levels of oxime and symptoms in humans after single and multiple oral doses of 2-pyridine aldoxime methochloride. J. Pharm. Sci. 58: $1093-1098$ (1969).

98. J. W. Estes, E. W. Pelikan, and E. Krüger-Thiemer. A retrospective study of the pharmacokinetics of heparin. Clin. Pharmacol. Therap. 10: 329-337 (1969).

99. J. G. Wagner. Design and data analysis of biopharmaceutical studies in man. Can.J. Pharm. Sci. 1: 55-68 (1966)

100. J. T. Doluisio and L. W. Dittert. Dosing of tetracyclines on biologic half-life in serum. Clin. Pharmacol. Therap. 10: 690-701 (1969).

101. J. Shibasaki, T. Koizumi, and T. Tanaka. Drug absorption, metabolism and excretion. I Some pharmacokinetic aspects of metabolism of acetanilide and 4-hydroxylacetanilide. Chem. Pharm. Bull. (Tokyo) 16: 1661-1673 (1968).

102. A. J. Glazko, T. Chang, J. Baukema, W. A. Dill, J. R. Goulet, and R. A. Buchanan. Metabolic disposition of diphenylhydantoin in normal human subjects following intravenous administration. Clin. Pharmacol. Therap. 10: 498-504 (1969).

103. T. Suzuki, Y. Saitoh, and K. Nishihara. Kinetics of diphenylhydantoin disposition in man. Chem. Pharm. Bull. (Tokyo) 18: 405-411 (1970).

104. M. Blum, I. McGilveray, C. Becker, and S. Riegelman. Clinical implications derived from pharmacokinetics of diphenylhydantoin (DPH). Clin. Res. 19: 121 (1971) (abst.).

105. K. Arnold and N. Gerber. The rate of decline of diphenylhydantoin in human plasma. Clin. Pharmacol. Therap. 11: 121-134 (1970).

106. N. Gerber and K. Arnold. Studies on the metabolism of diphenylhydantoin in mice. $J$. Pharmacol. Exptl. Therap. 167: 77-89 (1969).

107. N. Gerber, W. L. Weller, R. Lynn, R. E. Rangno, B. J. Sweetman, and M. T. Bush. Study of dose-dependent metabolism of 5,5-diphenylhydantoin in the rat using new methodology for isolation and quantitation of metabolites in vivo and in vitro. J. Pharmacol. Exptl. Therap. 178: 567-579 (1971).

108. N. Gerber and J. G. Wagner. Explanation of dose-dependent decline of diphenylhydantoin plasma levels by fitting to the integrated form of the Michaelis-Menten equation. Res. Commun. Chem. Pathol. Pharm. 3: 445-466 (1972).

109. J. G. Wagner. Properties of the Michaelis-Menten equation and its integrated form which are useful in pharmacokinetics. J. Pharmacokin. Biopharm. 1: 103-121 (1973).

110. K. Balasubramaniam, G. E. Mawer, and P. J. Simons. The influence of dose on the distribution and elimination of amylobarbitone in healthy subjects. Brit. J. Pharmacol. 40: 578P-579P (1970).

111. G. H. Mudge and I. M. Weiner. Renal excretion of weak organic acids and bases. In C. A. M. Hogben (ed.), Drugs and Membranes, Vol. IV, pp. 157-164.

112. I. M. Weiner and G. H. Mudge. Renal tubular mechanisms for excretion of organic acids and bases. Am. J. Med. S.i. 36: 743-762 (1964).

113. I. M. Weiner, K. C. Blanchard, and G. H. Mudge. Factors influencing renal excretion of foreign organic acids. Am. J. Physiol. 207: 953-963 (1964).

114. I. M. Weiner, J. E. Glasser, and L. Lack. Renal excretion of bile acids: Taurocholic, glycocholic and cholic acids. Am. J. Physiol. 207: 964-970 (1964).

115. A. H. Beckett and M. Rowland. Rhythmic urinary excretion of amphetamine in man. Nature 204: 1203-1204 (1964).

116. K. C. Huang and D. S. T. Lin. Kinetic studies on transport of PAH and other organic acids in isolated renal tubules. Am. J. Physiol. 208: 391-396 (1965). 
117. W. J. Jusko, G. Levy, S. Y. Yaffe, and R. Gorodescher. Effect of probenecid on renal clearance of riboflavin in man. J. Pharm. Sci. 59: 473-477 (1970).

118. W. J. Jusko, G. Levy, S. Y. Yaffe, and R. Gorodescher. Pharmacokinetic evidence for saturable renal tubular reabsorption of riboflavin. J. Pharm. Sci. 59: 765-772 (1970).

119. L. Dettli and P. Spring. Diurnal variations in the elimination rate of sulfonamide in man. Helv. Med. Acta 33: 291-306 (1966).

120. A. H. Beckett, R. N. Doyes, and G. T. Tucker. Use of the analogue computer to examine the quantitative relation between urinary $p \mathrm{H}$ and kidney reabsorption of drugs partially ionized at physiological $p H$. J. Pharm. Pharmacol. 20:269-276(1968).

121. A. H. Beckett, R. N. Boyes, and G. T. Tucker. Use of the analogue computer to predict the distribution and excretion of drugs under conditions of fluctuating urinary $p \mathrm{H}$. J. Pharm. Pharmacol. 20: 277-282 (1968).

122. M. Pfeffer, J. M. Schor, S. Bolton, and R. Jacobson. Human urinary excretion of the quaternary ammonium compounds anisotropine methylbromide and propantheline bromide. J. Pharm. Sci. 57: 1375-1379 (1968).

123. J. Shibasaki, T. Koizumi, and W. Higuchi. Drug absorption, metabolism and excretion. IV. Pharmacokinetic studies on renal transport. I. Simultaneous chemical reaction and diffusion (SCRD) model for uphill transport. Chem. Pharm. Bull. (Tokyo) 16: 2273-2277 (1968).

124. J. Shibasaki, R. Konishi, Y. Takeda, and T. Koizumi. Drug absorption, metabolism and excretion. VII. Pharmacokinetics of formation and excretion of the conjugates of $\mathrm{N}$ acetyl-p-aminophenol in rabbits. Chem. Pharm. Bull. (Tokyo) 19: 1800-1808 (1971).

125. A. R. DiSanto and J. G. Wagner. Pharmacokinetics of highly ionized drugs. II. Methylene blue-absorption, metabolism, and excretion in man and dog after oral administration. J. Pharm. Sci. 61: 1086-1094 (1972).

126. J. B. Nagwekar and A. Unnikrishnan. Michaelis-Menten kinetics of renal tubular secretion of $\mathrm{D}-(-)+p$-methyl mandelic acid and $\mathrm{D}-(-)$-p-ethyl mandelic acid in rats. $J$. Pharm. Sci. 60: 375-380 (1971).

127. L. S. Schanker. Concentrative transfer of an organic cation from blood into bile. Biochem. Pharmacol. 11: 253-254 (1962).

128. L. J. Schoenfield, D. B. McGill, and W. T. Foulk. Studies of sulfobromophthalein sodium (BSP) metabolism in man. III. Demonstration of a transport maximum ( $\mathrm{Tm}$ ) for biliary excretion of BSP. J. Clin. Invest. 43: 1424-1432 (1964).

129. R. T. Williams, P. Milburn, and R. L. Smith. The influence of enterohepatic circulation on toxicity of drugs. Ann. N.Y. Acad. Sci. 123: 110-124 (1965).

130. C. Lanman, S. Muranishi, and L. S. Schanker. Active transport of tetracycline into bile. Pharmacologist 12: 293 (1970) (abst.).

131. D. W. Yesair, M. Callahan, L. Remington, and C. J. Kensler. Role of the enterohepatic cycle of indomethacin on its metabolism, distribution in tissues and its excretion by rats, dogs and monkeys. Biochem. Pharmacol. 19: 1579-1590 (1970).

132. W. J. O'Reilly, P. A. Pitt, and A. J. Ryan. Pharmacokinetic model for the successive demethylation and biliary secretion of methyl orange in the rat. Brit. J. Pharmacol. 43: 167-179 (1971).

133. J. E. Axelson and M. Gibaldi. Absorption and excretion of riboflavin in the rat: An unusual example of nonlinear pharmacokinetics. J. Pharm. Sci. 61: 404-407 (1972).

134. J. G. Wagner. Kinetics of pharmacologic response. I. Proposed relationships between response and drug concentration in the intact animal and man. J. Theoret. Biol. 20: 173$201(1968)$.

135. A. R. DiSanto and J. G. Wagner. Kinetics of pharmacologic response. II. Equation for turnover time of goldfish as a function of concentration of ethanol and a theoretical derivation based on a combination of occupation and rate receptor theories. J. Pharm. Sci. 58: $1077-1085$ (1969).

136. M. Gibaldi and G. Levy. Dose-dependent decline of pharmacologic effects of drugs with linear pharmacokinetic characteristics. J. Pharm. Sci. 61: 567-569 (1972).

137. J. G. Wagner. Relations between drug concentration and response. J. Mondial de Pharmacie 14: 279-310 (1971). 
138. G. Levy and M. Gibaldi. Pharmacokinetics of drug action. Ann. Rev. Pharmacol 12: 85-98 (1972).

139. T. Tsuchiya and G. Levy. Relationship between dose and plateau levels of drugs eliminated by parallel first-order and capacity-limited kinetics. J. Pharm. Sci. 61 : 541-544 (1972).

140. E. Krüger-Thiemer. Pharmacokinetics and dose-concentration relationships. In Proceedings of the Third International Pharmacological Meeting, Sao Paulo, 1966, Vol. 7: Physico-Chemical Aspects of Drug Actions, Pergamon Press, New York, 1968, pp. 63-113.

141. E. Krüger-Thiemer and R. Levine. The solution of pharmacological problems with computers. VIII. Non first-order models of drug metabolism. Arzneim.-Forsch. 18: 1575$1579(1968)$.

142. P. A. Shore, B. B. Brodie, and C. A. M. Hogben. The gastric secretion of drugs; a $p \mathrm{H}$ partition hypothesis. J. Pharmacol. Exptl. Therap. 119: 361-369 (1957).

143. C. A. M. Hogben, D. J. Tocco, B. B. Brodie, and L. S. Schanker. On the mechanism of intestinal absorption of drugs. J. Pharmacol. Exptl. Therap. 125: 275-282 (1959).

144. A. Suzuki, W. I. Higuchi, and N. F. H. Ho. Theoretical model studies of drug absorption and transport in the gastrointestinal tract.II. J. Pharm. Sci. 59: 651-659 (1970)

145. L. Michaelis and M. L. Menten. Die Kinetic der Invertinwirkung. Biochem. Z. 49:333-369 (1913).

146. A. Goldstein. Saturation of alcohol dehydrogenase by ethanol. New Engl. J. Med. 283: 875 (1970).

147. J. G. Wagner. A new generalized nonlinear pharmacokinetic model and its implications. In Biopharmaceutics and Relevant Pharmacokinetics, 1st ed., Drug Intelligence Publications, Hamilton, Ill., 1971. Chap. 40, pp. 302-317.

148. A. R. DiSanto and J. G. Wagner. Potential erroneous assignment of nonlinear data to the classical linear two-compartment open model. J. Pharm. Sci. 61: 552-555 (1972).

149. M. Rowland and S. Riegelman. Pharmacokinetics of acetylsalicylic acid and salicylic acid after intravenous administration in man. J. Pharm. Sci. 57:1313-1319 (1968).

150. M. Rowland, L. Z. Benet, and S. Riegelman. Two-compartment model for a drug and its metabolite: Application to acetylsalicylic acid pharmacokinetics. J. Pharm. Sci. 59: 364-367 (1970).

151. J. P. Wagner. Fallacy in concluding there are zero order kinetics from blood level and urinary excretion data. J. Pharm. Sci. 56: 586-594 (1967).

152. J. G. Wagner. Pharmacokinetics. Ann. Rev. Pharmacol. 8: 67-93 (1968).

153. B. K. Martin. Potential effects of the plasma proteins on drug distribution. Nature 207: 274-276 (1965)

154. M. C. Meyer and D. E. Guttman. The binding of drugs by plasma proteins. J. Pharm. Sci. 57: 895-918 (1968).

155. J. J. Coffey, F. J. Bullock, and P. T. Schoenemann. Numerical solution of nonlinear pharmacokinetic equations; effects of plasma protein binding on drug distribution and elimination. J. Pharm. Sci. 60: 1623-1628 (1971).

156. S. H. Curry. Theoretical changes in drug distribution resulting from changes in binding to plasma proteins and to tissues. J. Pharm. Pharmacol. 22: 753-757 (1970).

157. E. Kruger-Thiemer, W. Diller, and P. Bunger. Pharmacokinetic models regarding protein binding of drugs. Antimicrob. Agents Chemotherap. (Wash.), pp. 183-191 (1965, 1966).

158. E. R. Reeve. The plasma albumin system: A first attempt at a kinetic description in dynamic clinical studies with radioisotopes. In Proceedings of a Symposium, Oak Ridge Institute of Nuclear Studies, 1963, U.S. Department of Commerce, TID 7678, Office of Technical Services, Washington, D.C., 1964, pp. 445-472.

159. J. M. Thorp. The influence of plasma proteins on the action of drugs. In T. B. Binns (ed.), Absorption and Distribution of Drugs, Williams and Wilkins, Baltimore, 1964, pp. 64-76.

160. J. R. Gillette. Factors affecting drug metabolism. Ann. N.Y. Acad. Sci. 179: 43-66 (1971).

161. R. L. Dedrick and K. B. Bischoff. Pharmacokinetics in applications of the artificial kidney. Chem. Engr. Prog. Symp. Ser. 64 : 32-44 (1968).

162. K. B. Bischoff, R. L. Dedrick, and D. S. Zaharko. Preliminary model for methotrexate pharmacokinetics. J. Pharm. Sci. 59: 149-154 (1970). 
163. A. R. DiSanto. A new nonlinear pharmacokinetic model with specific application to methylene blue. Ph.D. dissertation, University of Michigan, Ann Arbor, 1971.

164. M. Civen, B. M. Ulrich, B. M. Trimmer, and C. B. Brown. Circadian rhythms of liver enzymes and their relationship to enzyme induction. Science 157: 1563-1564 (1967).

165. F. M. Radzialowski and W. F. Bousquet. Circadian rhythm in hepatic drug metabolizing activity in the rat. Life Sci. 6: 2545-2548 (1967).

166. J. J. Burns and A. H. Conney. Enzyme stimulation and inhibition in the metabolism of drugs. Proc. Roy. Soc. Med. 58: $955-960$ (1965).

167. G. L. Atkins. A versatile digital computer program for non-linear regression analysis. Biochim. Biophys. Acta 252: 405-420 (1971).

168. G. L. Atkins. Some applications of a digital computer program to estimate biological parameters by non-linear regression analysis. Biochim. Biophys. Acta 252: 421-426(1971).

169. J. Buell and R. Kalaba. Quasilinearization and the Fitting of Nonlinear Models of Drug Metabolism to Experimental Kinetic Data, Technical Report USCEE-312, Electronic Sciences Laboratory, University of Southern California, Los Angeles, 1968.

170. A. J. Sedman and J. G. Wagner. Quantitative pooling of both parallel Michaelis-Menten formation equations and Langmuir-type equations for bindings of drugs to tissues. In Abstracts of Symposia and Contributed Papers Presented to the APhA Academy of Pharmaceutical Seiences at the 119th Annual Meeting of the American Pharmaceutical Association, Houston Texas, 1972, Vol. 2, No. 1, Abst. 16, p. 61.

171. G. Spears, J. G. T. Sneyd, and E. G. Loten. A method of deriving kinetic constants for two enzymes acting on the same substrate. Biochem. J. 125: 1149-1151 (1971).

172. J. L. Neal. Analysis of Michaelis kinetics for two independent saturable membrane transport functions. $J$. Theoret. Biol. 35: 113 118 (1972). 